\title{
Methylene Homologues of Artemisone: An Unexpected Structure-Activity Relationship and a Possible Implication for the Design of C10-Substituted Artemisinins
}

\author{
Yuet $\mathrm{Wu}_{,}^{[\mathrm{b}]}$ Ronald Wai Kung $\mathrm{Wu}^{[\mathrm{b}]}{ }^{\mathrm{K}}{ }^{\mathrm{d}}$ wan Wing Cheu, ${ }^{[\mathrm{b}]}$ lan D. Williams, ${ }^{[\mathrm{b}]}$ Sanjeev Krishna, ${ }^{[\mathrm{c}]}$ \\ Ksenija Slavic, ${ }^{[c]}$ Andrew M. Gravett, ${ }^{[\mathrm{d}]}$ Wai M. Liu, ${ }^{[\mathrm{d}]}$ Ho Ning Wong, ${ }^{[\mathrm{a}, \mathrm{b}]}$ and \\ Richard K. Haynes ${ }^{*[a, b]}$
}

\begin{abstract}
We sought to establish if methylene homologues of artemisone are biologically more active and more stable than artemisone. The analogy is drawn with the conversion of natural $O$ and $\mathrm{N}$-glycosides into more stable $\mathrm{C}$-glycosides that may possess enhanced biological activities and stabilities. Dihydroartemisinin was converted into 10 $\beta$-cyano-10-deoxyartemisinin that was hydrolyzed to the $\alpha$-primary amide. Reduction of the $\beta$-cyanide and the $\alpha$-amide provided the respective methylamine epimers that upon treatment with divinyl sulfone gave the $\beta$ - and $\alpha$-methylene homologues, respectively, of artemisone. Surprisingly, the compounds were less active in vitro than artemisone against $P$. falciparum and displayed no appreciable activity against A549, HCT116, and MCF7 tumor cell lines. This loss in activity may be rationalized in terms of one model for the mechanism of action of artemisinins, namely the
\end{abstract}

cofactor model, wherein the presence of a leaving group at C10 assists in driving hydride transfer from reduced flavin cofactors to the peroxide during perturbation of intracellular redox homeostasis by artemisinins. It is noted that the carba analogue of artemether is less active in vitro than the O-glycoside parent toward P. falciparum, although extrapolation of such activity differences to other artemisinins at this stage is not possible. However, literature data coupled with the leaving group rationale suggest that artemisinins bearing an amino group attached directly to $\mathrm{C} 10$ are optimal compounds. A brief critique is made of proteomic studies purporting to demonstrate the alkylation of intraparasitic proteins by alkyne- and azide-tagged artemisinins and synthetic peroxides in relation to mechanism of action.

\section{Introduction}

Artemisinin (1) and its derivatives dihydroartemisinin (DHA, 2), artemether (3), and artesunate (4) have high parasite kill rates with broad-stage specificity, and they elicit faster clinical and parasitological responses than any other antimalarial drug. ${ }^{[1]}$ However, all are thermally and chemically fragile, and as exemplified by $\mathrm{DHA}$, the thermal instability engenders problems during formulation and storage. ${ }^{[2]}$ DHA undergoes facile

[a] Dr. H. N. Wong, Prof. R. K. Haynes

Centre of Excellence for Pharmaceutical Sciences, Faculty of Health Sciences, North-West University, Potchefstroom 2520 (South Africa) E-mail: richard.haynes@nwu.ac.za

[b] Dr. Y. Wu, R. W. K. Wu, Dr. K. W. Cheu, Prof. I. D. Williams, Dr. H. N. Wong, Prof. R. K. Haynes

Department of Chemistry, The Hong Kong University of Science and Technology, Clear Water Bay, Kowloon, Hong Kong (P.R. China)

E-mail: haynes@ust.hk

[c] Prof. S. Krishna, Dr. K. Slavic

Centre for Infection, Division of Cellular and Molecular Medicine, St. George's Hospital, University of London, SW17 ORE (UK)

[d] Prof. A. M. Gravett, Dr. W. M. Liu

Department of Oncology, Division of Cellular and Molecular Medicine, St. George's Hospital, University of London, Jenner Wing, London SW17 ORE (UK)

$\square$ Supporting Information for this article can be found under http:// dx.doi.org/10.1002/cmdc.201600011. phase I metabolism ${ }^{[3]}$ and rearranges under physiological conditions at $\mathrm{pH} 7.4$ to peroxyhemiacetal $\mathbf{5}_{{ }^{[4]}}$ which is observed in the plasma of patients treated with artesunate ${ }^{[5]}$ Artesunate is rapidly hydrolyzed to $\mathrm{DHA}$ in vivo, ${ }^{\left[{ }^{[6]}\right.}$ but likely because of the protective effect of the ester group against first-pass metabolism, it is a better source of DHA in plasma than DHA itself. ${ }^{[7]}$ The facile metabolism of artemether to DHA is reflected in the detection of the latter compound in subjects administered with artemether. ${ }^{[8]}$

Artemisinins, especially DHA, elicit neurotoxicity in cell and animal assays. ${ }^{[9,10]}$ The neurotoxicity of DHA reaches the level of activity that the drug displays in vitro against $P$. falciparum. ${ }^{[9]}$ Although debate over the neurotoxicity of artemisinin $s^{[11,12]}$ has subsided, the emerging resistance of the malaria parasite to chemotherapy involving current clinical artemisinins 2-4 in Cambodia and other countries in south-east Asia ${ }^{[13]}$ now necessitates administration of more protracted treatment regimens. This mandates renewed vigilance of the neurotoxicity. ${ }^{[12]} \mathrm{Neu}-$ rotoxicity is also of concern wherein protracted treatment regimens involving artemisinins are required for treatment of other diseases. ${ }^{[14]}$ Driven by the need to maintain an effective antimalarial drug generation campaign that in view of the resistance to the current clinical artemisinins has become a most urgent task, a number of groups has prepared new derivatives 


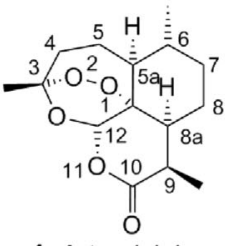

1: Artemisinin

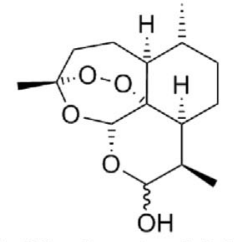

2: Dihydroartemisinin

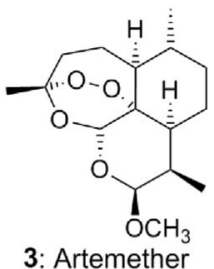

$\log P: 3.51$
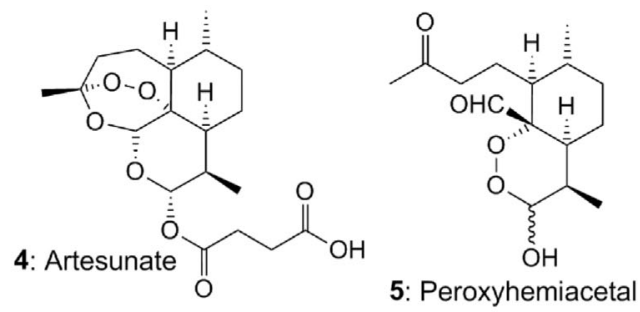

and analogues that do not have the shortcomings of the current clinical artemisinins. ${ }^{[15-17]}$ In the absence of an understanding of the mechanism of action of artemisinin at the time we commenced our own work in this area, we used a straightforward paradigm: because of neurotoxicity concerns, the derivative should not generate DHA in vivo and should not be too lipophilic. ${ }^{[18,19]}$ This guided us in the preparation of $\mathrm{C} 10$ amino derivatives such as compounds $\mathbf{6 - 8}$ with $\mathrm{IC}_{50}$ values in vitro ranging from 0.25 to $0.63 \mathrm{nM}$ against multidrug-resistant and sensitive strains of $P$. falciparum. ${ }^{[20,21]}$ In contrast, values for artemether lie approximately between $2-5 \mathrm{~nm}^{\left[{ }^{1 b]}\right.}$ The development candidate eventually chosen was artemisone 9. The "stop-go" criterion was its lack of neurotoxicity ${ }^{[22]}$ coupled with acceptable physicochemical properties and an efficacy of approximately $1 \mathrm{~nm}$ against multidrug-resistant and sensitive strains of $P$. falciparum. The relatively low calculated $(2.08)^{[23]}$ and measured $\log P$ (2.49) values and acceptable water solubility at $\mathrm{pH} 7.2$ of $89 \mathrm{mg} \mathrm{L}^{-1}$ mark artemisone as a relatively polar compound. ${ }^{[21]}$ In comparison, artemether has a calculated $\log P$ of 3.51 , a measured $\log P$ of 3.98 , and a water solubility at $\mathrm{pH} 7.2$ of $117 \mathrm{mg} \mathrm{L}^{-1}$. ${ }^{21]}$

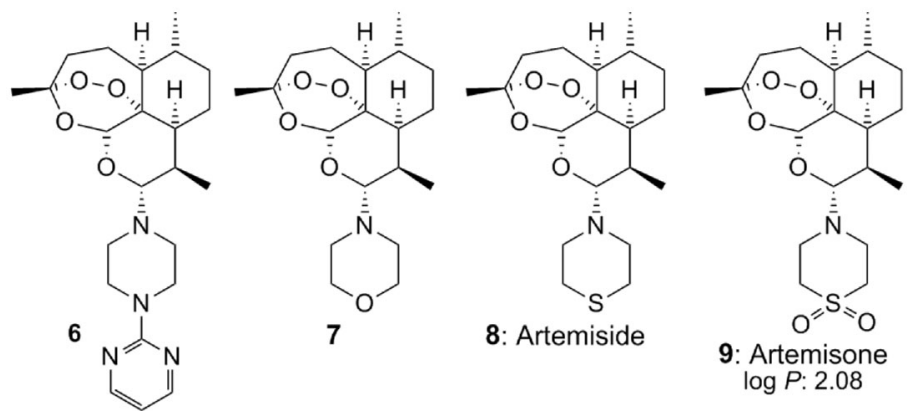

regimen of artemisone, corresponding to a total dose level of one third of that of the comparator drug artesunate, followed by a final dose of mefloquine was curative. The relatively minor amounts of metabolites in plasma of the patients did not include DHA. Both artemisone and its precursor artemiside (8) display substantially better inhibition than either artemisinin or artesunate in vitro against another apicomplexan organism, namely Toxoplasma gondii. ${ }^{[29]}$ Artemisinins possess anticancer properties. ${ }^{[14,30]}$ The efficacy of artemisone both alone and in combination with common anticancer agents was established with in vitro assays. Artemisinin (1) and artemisone (6) each caused dose-dependent decreases in cell number with $\mathrm{IC}_{50}$ values significantly better in the latter. Combination studies showed that the antiproliferative effect of artemisone was enhanced by the addition of other drugs. ${ }^{[31]}$ Artemisone is among the most potent of all peroxides upon screening against a panel of multidrug-sensitive and resistant tumor cell lines. ${ }^{[32]}$ Thus, overall, and in particular because of non-neurotoxicity, artemisone represents an attractive drug candidate for treatment of malaria and other targets, especially those for which protracted treatment regimens may be required.

However, one crucial aspect that was not satisfactorily addressed is of stability. ${ }^{[2]}$ The thermal stability of artemisone is similar to that of artesunate. Although at $\mathrm{pH} 7.2$ artemisone is hydrolytically stable (in contrast to artesunate), at $\mathrm{pH} 1.2$, just like artesunate, ${ }^{[5]}$ it is relatively rapidly hydrolyzed to $\mathrm{DHA} .{ }^{[33]}$ The hydrolysis likely is initiated by protonation of the C10 nitrogen atom followed by cleavage to oxonium ion 10 that adds water to generate DHA (Scheme 1). ${ }^{[15]}$ It is this relative instability at low $\mathrm{pH}$ that needs to be addressed if a robust and equipotent successor at least to artemisone is to emerge.

We sought to bypass this problem by preparing

Metabolism of artemisone to DHA does not take place, and it is not an inducer of its own metabolism. Artemisone is more potent than artesunate, especially against multidrug-resistant Plasmodium parasites, ${ }^{[24]}$ and is approximately 2-6 times more potent in vitro than synthetic trioxolane development candidates. ${ }^{[1,16,25,26]}$ Artemisone was the most efficient drug tested in a murine model of cerebral malaria and prevented death even when administered at late stages of cerebral pathogenesis. ${ }^{[27]}$ Treatment of non-severe falciparum malaria in a primate model with combinations of artemisone with other antimalarial drugs was markedly superior to the same combinations containing the comparator drug artesunate ${ }^{[28]} \mathrm{A}$ phase lla trial involving oral treatment of malaria patients with a 2 day dose amino derivatives with a nitrogen atom at $\mathrm{C} 10$ rendered less basic by electron-withdrawing groups, as exemplified by polarsubstituted sulfamide 11 (with a calculated $\log P$ of 1.24) to be described elsewhere. In complement with this approach, we evaluated a second proposal for enhancing stability at low $\mathrm{pH}$. The $\mathrm{C} 10-\mathrm{N} 1^{\prime}$ bond in artemisone (9) (Scheme 1) corresponds to the $\mathrm{N}$-glycoside linkage in $\mathrm{N}$-glycosyl amines, wherein the glycosyl moiety equates with the pyran ring of the artemisinin nucleus. Attempts to develop carbohydrate-based therapeutic agents have been complicated by the lability of $\mathrm{N}$ - and $\mathrm{O}$ acetal linkages between the carbohydrate and its bioconjugate under weakly acidic conditions. A solution to this problem lies in the replacement of the glycoside heteroatom with a carbon 


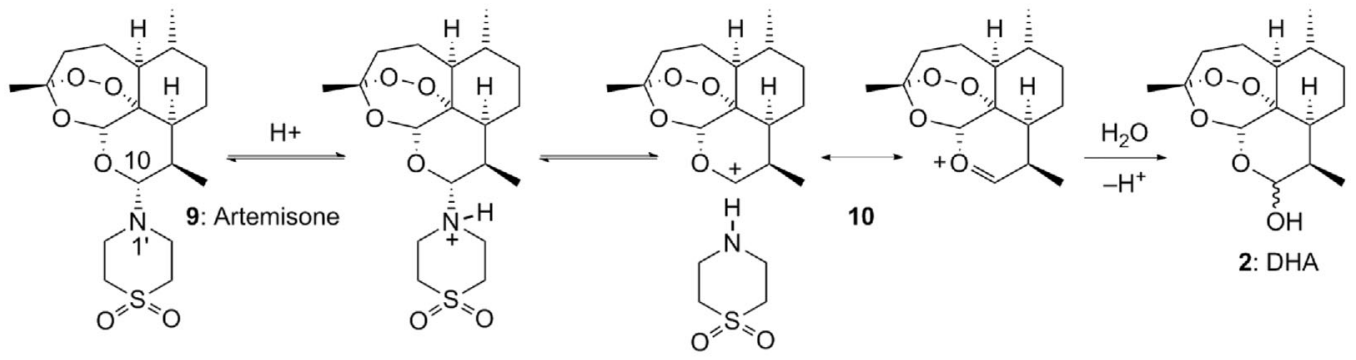

Scheme 1. $\mathrm{S}_{\mathrm{N}} 1$ decomposition pathway for artemisone proceeding via oxonium ion 10 under aqueous acidic conditions.

atom to provide unnatural $C$-glycosides that are resistant to degradation. Although there are conformational differences between natural and C-glycosides, ${ }^{[34]}$ the latter usually retain the biological properties of the original carbohydrates. ${ }^{[35]} \mathrm{A}$ relevant example is provided by the glycolipid $\alpha$-galactosylceramide (KRN7000, 12) that exhibits potent antimalarial and antitumor activities. The synthetic analogue 13, in which the exocyclic heteroatom is replaced with a methylene group, is 1000fold more active than $\mathbf{1 2}$ against liver stages of Plasmodium yoelii in a murine malaria model and 100 -fold more potent in inhibiting metastasis in a murine melanoma model. ${ }^{[36]}$

Thus, the insertion of a methylene group $\left(-\mathrm{CH}_{2}-\right)$ between the artemisinin nucleus and the thiomorpholine-S,S-dioxide ring was planned. This will generate the methylene homologues $\mathbf{1 4}$ and the epimer $\mathbf{1 5}$ of artemisone. In addition to enhancing stability, the methylene group should provide additional degrees of freedom to the molecule. If the thiomorpholine-S,S-dioxide is responsible for the enhanced efficacy of artemisone, likely through enhancing permeability, ${ }^{[20]}$ or if it assists in any interaction with proteins or receptors within the malaria parasite or tumor cell, the homologues are expected to be more active than artemisone. Such a transformation will not adversely affect compound polarities: calculated $\log P$ values ${ }^{[23]}$ for compounds 14 and 15 are each 1.7 (cf. artemisone 2.08).

\section{Results and Discussion}

\section{Preparation of methylene artemisones}

The nitrile 17 was prepared in $76 \%$ yield from the $\alpha$-acetate of DHA and trimethylsilyl cyanide with $\mathrm{TiCl}_{4}$ as the catalyst in dichloromethane. ${ }^{[37]}$ We varied this procedure by converting
DHA (2) into the $\beta$-benzoate 16 by the Schmidt reaction. ${ }^{[38]}$ The benzoate was treated with trimethylsilyl cyanide and $\mathrm{SnCl}_{4}$ as the catalyst to give solely the $\beta$-nitrile 17 in $83 \%$ yield after direct crystallization (Scheme 2). This compound arises by an $\mathrm{S}_{\mathrm{N}} 1$ reaction involving oxonium ion 10 (Scheme 1) formed from the $\beta$-benzoate 16 and $\mathrm{SnCl}_{4} \cdot{ }^{[15,38]}$ The X-ray crystal structure (Figure S1, Supporting Information) indicates that the cyanide is axial on the chair pyranose ring. Although sterically more hindered than the equatorial cyanide in the $\alpha$ epimer because of 1,3-diaxial interactions with the $\mathrm{C} 8-\mathrm{C} 8 \mathrm{a}$ bond, ${ }^{[38]}$ the axial cyanide is subject to anomeric stabilization involving $\sigma^{*}$ $\mathrm{n}$ orbital overlap, as in other derivatives of DHA. ${ }^{[15,38,39]}$

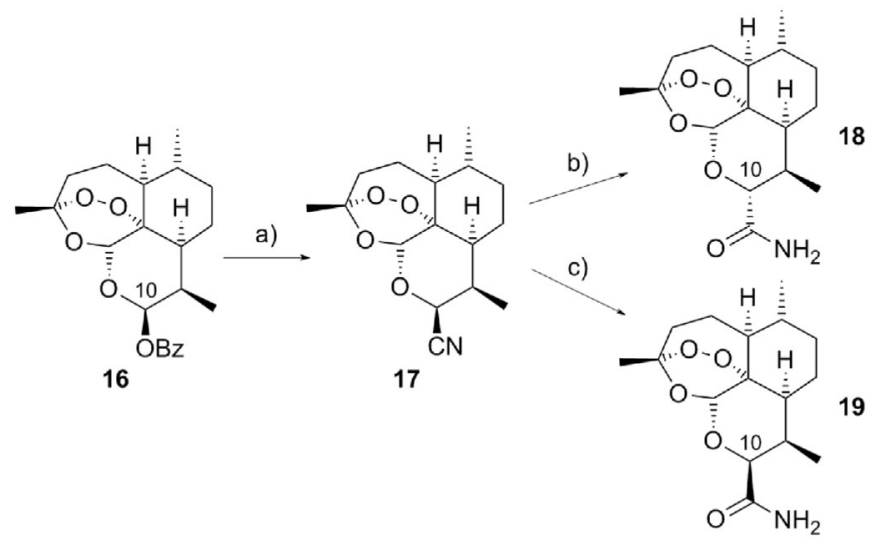

Scheme 2. Preparation of $\beta$-nitrile 17 and conversion into 10 - $\alpha$-amide 18 and 10- $\beta$-amide 19. Reagents and conditions: a) $\mathrm{Me}_{3} \mathrm{SiCN}$ (3.0 equiv), $\mathrm{SnCl}_{4}$ (0.3 equiv), $\mathrm{CH}_{2} \mathrm{Cl}_{2},-78^{\circ} \mathrm{C}, 2 \mathrm{~h}$, quench; direct crystallization from propan-2ol, $83 \%$; b) $\mathrm{KOH}$ (3.5 equiv), $\mathrm{tBuOH}, 50{ }^{\circ} \mathrm{C}, 3.5 \mathrm{~h}$, quant.; c) $\mathrm{K}_{2} \mathrm{CO}_{3}$ (1.1 equiv), $\mathrm{H}_{2} \mathrm{O}_{2}$ (30\%, 15.0 equiv), THF, RT, $2 \mathrm{~h}$ then $40^{\circ} \mathrm{C}, 30 \mathrm{~min}, 29 \%$ ( $\mathrm{Bz}=$ benzoyl).

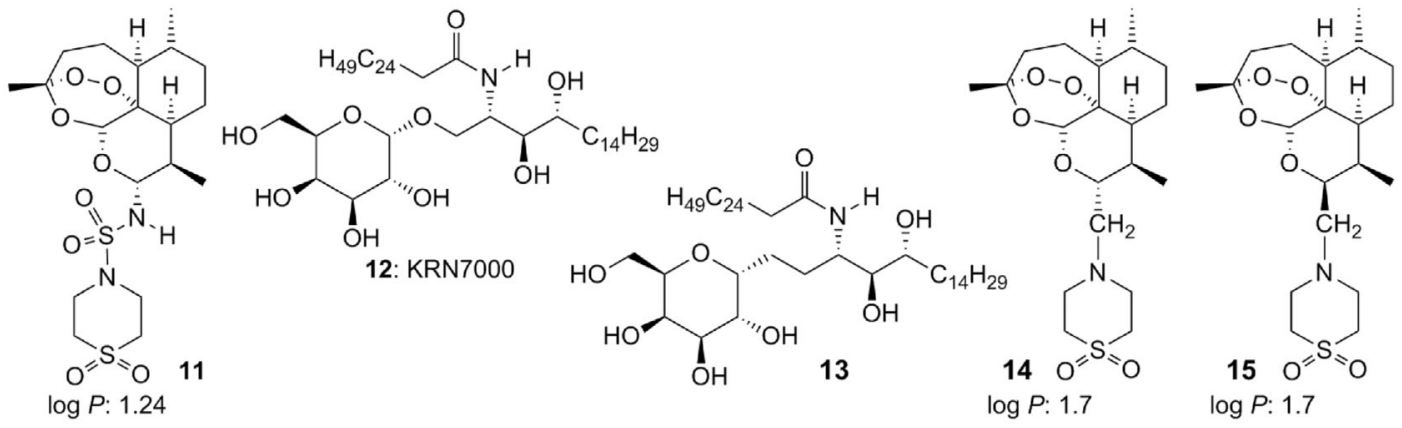


Because of the potential lability of the 1,2,4-trioxane unit under the strongly acidic conditions normally required for the hydrolysis of nitriles, hydrolysis in the presence of base was carried out. The Hall method ${ }^{[40]}$ was adapted by heating a mixture of the nitrile and potassium hydroxide in tert-butyl alcohol at $50^{\circ} \mathrm{C}$, whereby the potassium hydroxide dissolved completely and the $\alpha$-amide $\mathbf{1 8}$ was formed in quantitative yield (Scheme 2). At higher temperatures, decomposition took place. The other method ${ }^{[41]}$ involved the use of a mixture of aqueous hydrogen peroxide and potassium carbonate in tetrahydrofuran (Scheme 2). The reaction provided the $\beta$-amide in $29 \%$ yield. This fortuitous means of obtaining each amide epimer allowed for the unambiguous assignment of stereochemistry to each compound. In the ${ }^{1} \mathrm{H}$ NMR spectrum of $\alpha$-epimer 18 , $J_{10,9}=11.2 \mathrm{~Hz}$, indicative of a trans-diaxial arrangement of $\mathrm{H} 10$ and $\mathrm{H} 9$, and in $\beta$-epimer 19, $J_{10,9}=6.2 \mathrm{~Hz}$, indicative of a cisaxial-equatorial relationship. ${ }^{[38]}$ The structure of amide $\mathbf{1 8}$ was confirmed by X-ray crystallography, wherein the trans-diaxial relationship between $\mathrm{H} 9$ and $\mathrm{H} 10$ is apparent (Figure S2). The evident relaxation of the anomeric effect for the carboxamide substituent coupled with a greater 1,3-diaxial interaction involving the axial amide with the C8-C8a bond in $\beta$-amide 19 that must be formed initially from nitrile 17 allows for basecatalyzed equilibration to give equatorial epimer 18 (Scheme 3).

Although the peroxide restricts the type of reagents that may be used for reduction of nitriles or amides to amines, treatment of nitrile $\mathbf{1 7}$ and amide $\mathbf{1 8}$ with an excess of sodium borohydride-boron trifluoride in tetrahydrofuran ${ }^{[42]}$ worked well to provide crude aminomethyl artemisinin derivatives 20 and 21. The thiomorpholine-S,S-dioxide ring was then constructed around the primary amino groups in 20 and 21 by treatment of the crude amines with divinyl sulfone in isopropa- nol ${ }^{[43,44]}$ to give the crystalline $\alpha$-homologue 14 of artemisone in $40 \%$ yield from $\alpha$-amide 19 and the crystalline $\beta$-homologue 15 in $45 \%$ yield from nitrile 17 (Scheme 4).

According to X-ray crystallography, the $\alpha$ epimer possesses a chair pyranose ring, as is the case with artemisone, ${ }^{[20]}$ whereas the $\beta$ epimer has a slightly twisted half-chair pyranose ring that attenuates the diaxial interaction between the $\mathrm{C} 10$ methylene substituent and the axial C8-8a bond (Figure 1). Notably, the thiomorpholine-S,S-dioxide ring does not shield the peroxide bridge in either the $\alpha$ or $\beta$ homologues; in both cases the ring projects away from the trioxane nucleus. As outlined below, the relative orientation of the thiomorpholine-S,S-dioxide ring in each of the compounds has no significant effect on the biological activities of the homologues. Mechanistic considerations aside, this is significant, as antimalarial activities of artemisinins are sensitive to steric effects. Thus, for example, 9epiartemisinin with a C9 $\alpha$-axial methyl group that flanks the peroxide has relative activities ranging between 0.14 (D6) and 0.67 (W2) of those of artemisinin. ${ }^{[45]}$

\section{Biological activities}

Artemisone (9) and methylene homologues 14 and 15 were screened in vitro against the chloroquine (CQ)-sensitive 3D7 strain of Plasmodium falciparum. Data are given in Table 1 and dose-response curves are presented in Figure S3. It is emphasized that screening involving compounds 9, 14, and 15 was carried out simultaneously in the one experimental set, that is, differences in activities between artemisone and the homologues are not artefactual. Thus, the homologues have comparable activities, yet both are approximately an order of magnitude less active than artemisone (9).

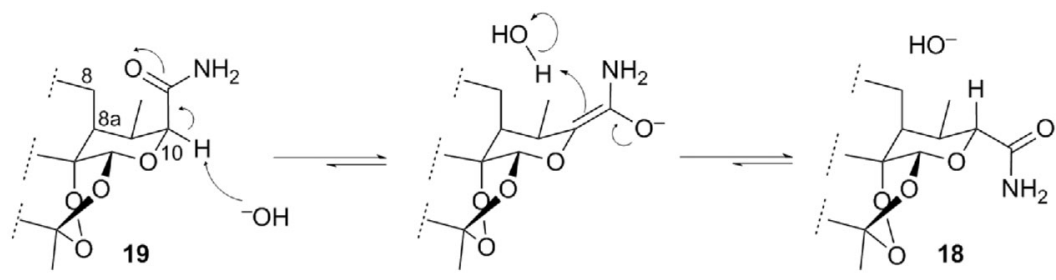

Scheme 3. Base-mediated conversion of axial amide 19 into equatorial amide 18.

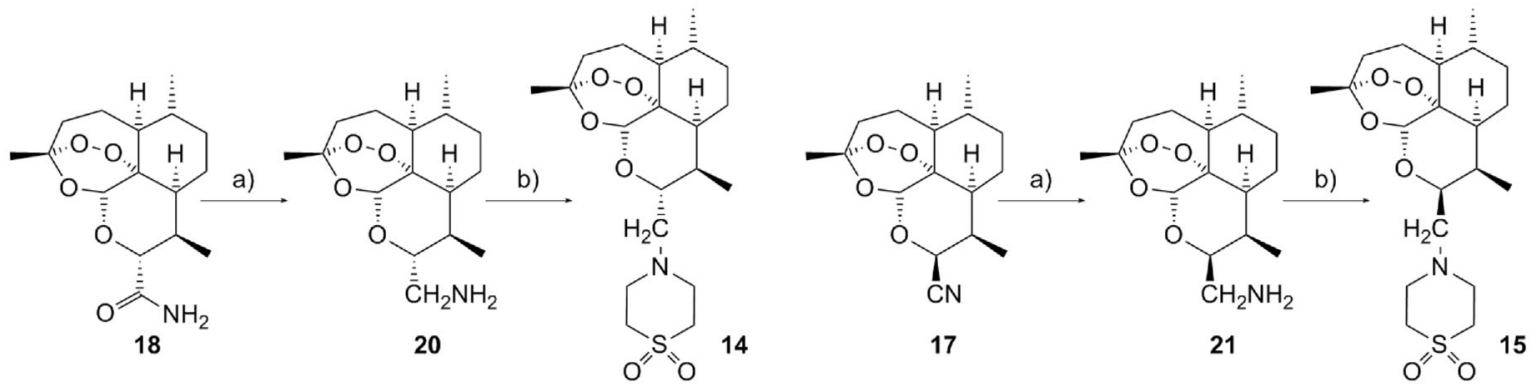

Scheme 4. Conversion of nitrile 17 and amide 18 into methylene artemisone homologues. Reagents and conditions: a) $\mathrm{NaBH}_{4}\left(5.0\right.$ equiv), $\mathrm{BF}_{3} \cdot \mathrm{OEt}_{2}(5.0$ equiv), THF, reflux, $2 \mathrm{~h}$; b) divinyl sulfone (2.0 equiv), isopropanol, reflux, $2 \mathrm{~h} ; 14: 40 \%$ from amide 18, 15: $45 \%$ from nitrile 17. 


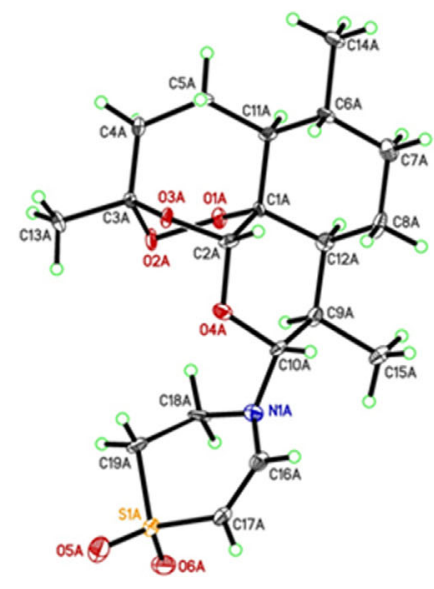

9

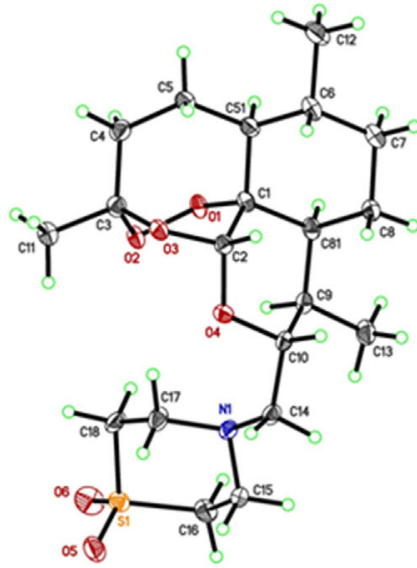

14

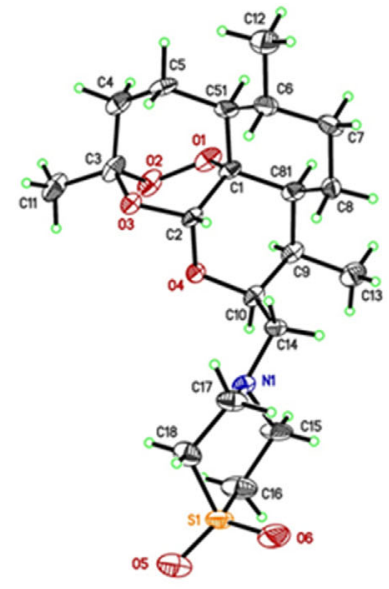

15

Figure 1. ORTEP plots obtained from X-ray crystallographic structural determination of artemisone (9), $\alpha$-methylene artemisone (14) and $\beta$-methylene artemisone (15).

Table 1. Activities in vitro of artemisone (9), $\alpha$-methylene artemisone (14), and $\beta$-methylene artemisone (15) against $P$. falciparum CQ-sensitive 3D7 strain.

\begin{tabular}{|ll|}
\multicolumn{1}{|c|}{ Compound } & $\mathrm{IC}_{50}[\mathrm{~nm}]^{[\mathrm{a}]}$ \\
\hline artemisone (9) & $1.09 \pm 0.105$ \\
$\alpha$-methylene artemisone (14) & $8.85 \pm 1.68$ \\
$\beta$-methylene artemisone (15) & $8.50 \pm 1.59$ \\
\hline
\end{tabular}

[a] Three independent experiments for each entry; evaluated with the $\left[{ }^{3} \mathrm{H}\right]$ hypoxanthine incorporation assay.

Screening against A549 (lung adenocarcinoma epithelial), HCT116 (colon), and MCF7 (breast) tumor cells was carried out. Cell-counting experiments with either the 3-(4,5-dimethylthiazol-2-yl)-2,5-diphenyltetrazolium bromide (MTT) or trypan blue assays indicated no observable effects for both compounds against all cancer cell lines (Figure S4). Also, according to fluorescence-activated cell sorting (FACS) analyses, there was no clear effect for both homologues; probably there was a blockade at the intermediate-grade $G_{2}$ level of cancer cells. There may be a growth inhibitory effect at concentrations $<1 \mu \mathrm{M}$, which may be at the level of $G_{2}$, but this is far from clear. In notable contrast, artemisone displays $I_{50}$ values of $9.5 \pm$ $0.9 \mu \mathrm{M}$ against HCT166 and $0.56 \pm 0.17 \mu \mathrm{M}$ against MCF7 cell lines and like artemisinins in general blocks at the $G_{1} / G_{2}$ phase. $^{[31,32]}$

\section{Mechanistic aspects}

We have used the $\mathrm{NAD}(\mathrm{P}) \mathrm{H}$ :flavin oxidoreductase $E$. coli flavin reductase (Fre) as a mimic of flavin disulfide reductases that maintain redox homeostasis in the malaria parasite. ${ }^{[4]}$ Fre does not contain a flavin cofactor but reduces endogenous flavins such as flavin adenine dinucleotide (FAD), flavin mononucleotide, and riboflavin (RF) and exogenous oxidants such as methylene blue that bind to a receptor in the $\mathrm{N}$-terminal domain by transferring a hydride from $\mathrm{NAD}(\mathrm{P}) \mathrm{H}$ bound in a proximate site in the C-terminal domain. ${ }^{[47,48]}$ Thus, the FAD cofactor crucial for reduction of disulfides to thiols by parasite flavin disulfide reductases is cleanly and rapidly reduced by $\mathrm{NAD}(\mathrm{P}) \mathrm{H}-\mathrm{Fre}$ to the reduced conjugate $\mathrm{FADH}_{2}$ in aqueous buffer under physiological conditions at $\mathrm{pH}$ 7.4. The reactions are conveniently followed by UV spectroscopy. Treatment of the $\mathrm{FADH}_{2}$ generated in this fashion with artemisinins such as artemisinin (1), artemether (3), artesunate (4), and artemisone (9) results in rapid oxidation of $\mathrm{FADH}_{2}$ to $\mathrm{FAD}$ and concomitant reduction of the artemisinins to deoxyartemisinins. For artemisone (9), the pathway is depicted in Scheme $5 \mathrm{~A}$, wherein hydride transfer results in cleavage of the peroxide and expulsion of the thiomorpholine-S,S-dioxide ring; this leads to the ring-opened intermediate $\mathbf{2 2}$, which gives deoxydihydroartemisinin $\mathbf{2 3}$ and its epimer 24 as described in detail elsewhere. ${ }^{[4,46]}$ The reduction also can be effected by using an excess amount of the NADPH mimic $\mathrm{N}$-benzyl-1,4-dihydronicotinamide (BNAH) in the presence of lumiflavine or riboflavin and artemisone in aqueous $\mathrm{pH} 7.4$ buffer that allows for isolation and characterization of the reduction products from the artemisinin derivative. ${ }^{[4]}$ The reduction also works for totally synthetic antimalarial peroxides. Thus, a trioxolane and a tetraoxane were readily reduced by the NADPH-Fre-FAD system to the corresponding ketones; the more active trioxolane was more rapidly reduced. Thereby, an approximate correlation between the relative rates of oxidation of $\mathrm{FADH}_{2}$ with the in vitro antimalarial activities of the peroxide substrates can be drawn. ${ }^{[46]}$ Overall, it is argued that the rate of intraparasitic redox perturbation should be considered as an important determinant of in vitro antimalarial activities. ${ }^{[49]}$

The Fre experiments were repeated here with artemisone (9) and methylene artemisones 14 and 15 (Figure 2). $\mathrm{FADH}_{2}$ was first prepared by reduction of FAD (1 equiv) by $\mathrm{NADH}-$ Fre in degassed pH 7.4 aqueous buffer solution. Then, each compound ( 2 equiv each with respect to $F A D$ in degassed $M e C N$ ) was injected into the $\mathrm{FADH}_{2}$ solution. The relative reaction rate was compared with that of the artemisone control experiment 


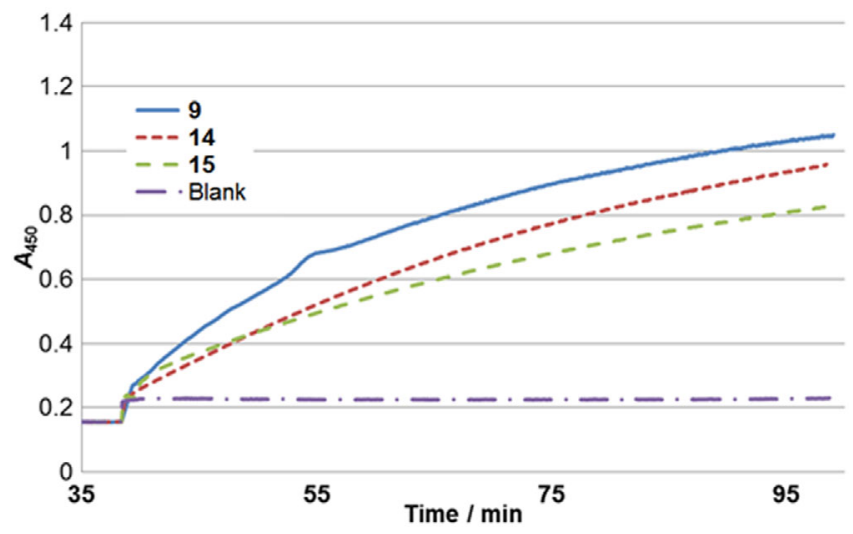

Figure 2. Oxidation of $\mathrm{FADH}_{2}$ generated from NADH-Fre-FAD by artemisone (9), $\alpha$-methylene artemisone (14), and $\beta$-methylene artemisone (15). FAD $(230 \mathrm{nmol})$ was added to NADH $(278 \mathrm{nmol})-$ Fre $(0.1 \mathrm{nmol})$ in aqueous buffer (pH 7.4) under an atmosphere of argon and decay of FAD was followed by monitoring the decrease in the absorbance at $\lambda_{\max }=450 \mathrm{~nm}$ every $3 \mathrm{~s}$ until the FAD absorbance no longer decreased. The $\mathrm{FADH}_{2}$ solution was treated with $\alpha$-methylene artemisone 14 (402 nmol, 2 equiv, in degassed MeCN) and the increase in the absorbance at $\lambda_{\max }=450 \mathrm{~nm}$ was monitored until constant (brown line). The experiment was repeated with $\beta$-methylene artemisone $(15 ; 402 \mathrm{nmol}, 2$ equiv) (green line). The relative rates of oxidations were compared with that of artemisone $(9 ; 400 \mathrm{nmol}, 2$ equiv) (blue line) and a blank experiment wherein degassed $\mathrm{MeCN}$ alone was added to the $\mathrm{FADH}_{2}$ solution (purple line).
(Figure 2). Although a faster reaction was observed with compound 14, both homologues oxidized $\mathrm{FADH}_{2}$ more slowly than artemisone. In principle, reduction of the methylene artemisone, for example 14, to the corresponding deoxy compounds, for example 26 (Scheme 5B), should have taken place under these conditions. However, attempted isolation of pure products from the NADH-FAD-Fre reactions conducted as above with each of the methylene artemisones or from the reaction of methylene artemisone 14 (1 equiv) with BNAH ( 2 equiv) -RF ( 0.2 equiv) in degassed $\mathrm{pH} 7.4 \mathrm{MeCN}$-phosphate buffer solution (1:1) under an atmosphere of argon (cf. Scheme 5B) was not successful. Apart from small amounts of unreacted methylene artemisone 14, complex product mixtures were obtained, and attempts to isolate discrete products from these mixtures were not successful. However, direct analyses of the chromatography fractions by mass spectrometry showed that the ringopened precursor $\mathbf{2 5}$ or equivalent (MS: $\mathrm{m} / \mathrm{z}$ : calcd for $\mathrm{C}_{20} \mathrm{H}_{36} \mathrm{NO}_{6} \mathrm{~S}^{+}$: 418.2258; found: 418.2232) and deoxy product 26 (MS: $\mathrm{m} / \mathrm{z}$ : calcd for $\mathrm{C}_{20} \mathrm{H}_{34} \mathrm{NO}_{5} \mathrm{~S}^{+}$: 400.2152; found: 400.2132) were present. Other products likely arising from decomposition of ring-opened precursor $\mathbf{2 5}$ were also detected. Full details are given in the Supporting Information and Figure S6.

A)<smiles>[R]N1c2ccccc2N([R])c2c1c(=O)[nH]c(=O)n2[2H]</smiles><smiles>[R]n1c2nc(=O)[nH]c(=O)c-2nc2ccccc21</smiles>

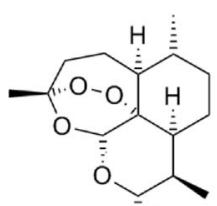

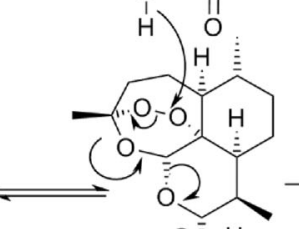<smiles>[B][13CH]1CCN2CCS(=O)(=O)C1C2</smiles><smiles>CN1CCS(=O)(=O)CC1</smiles>

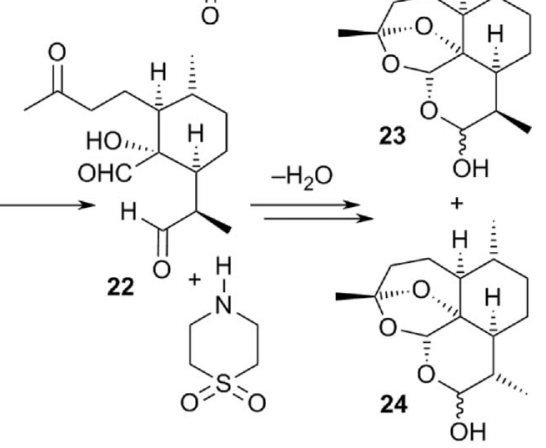

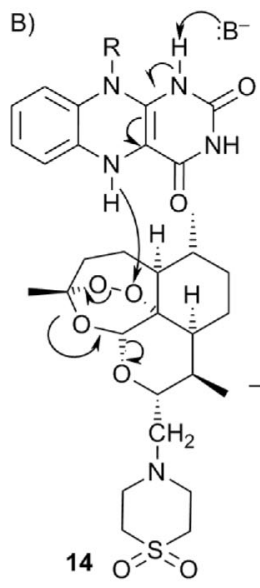<smiles>[R]n1c2nc(=O)[nH]c(=O)c-2nc2ccccc21</smiles>
YO<smiles>CC=CN=CC(N)=O</smiles>

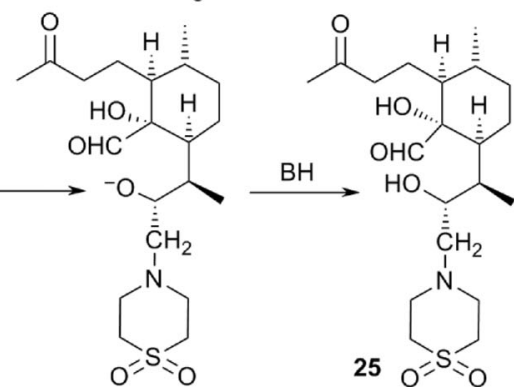<smiles>C#CC#CC</smiles>

Scheme 5. A) Reduction of artemisone (9) by hydride transfer from $\mathrm{FADH}_{2}(\mathrm{R}=\mathrm{D}$-ribitol-5-diphosphate adenosine, $\mathrm{BH}=$ protic acid in cellular medium) to generate $\mathbf{2 2}$ as the ring-opened precursor of deoxydihydroartemisinin 23, epimer 24, and other products (for detailed discussions, see Refs. [4, 47,50]). B) Proposed reduction of methylene artemisone homologue $\mathbf{1 4}$ proceeding via intermediate $\mathbf{2 5}$; in this case, discrete products corresponding to deoxy product $\mathbf{2 6}$ could not be isolated, although these were identified in product mixtures by mass spectrometry. 


\section{Discussion}

The results of the efficacy studies are unexpected, and contrast with the enhancement in antimalarial and antitumor activities brought about by inserting methylene units into glycolipid 12 to generate analogue 13 . In terms of absorption, the thiomorpholine S,S-dioxide group bestows acceptable physicochemical properties on artemisone, ${ }^{[20,21]}$ including an enhancement in polarity. However, the group may have another less apparent but important role in enhancing antimalarial activity. According to one model put forward for the antimalarial mechanism of action of artemisinins, namely the cofactor model, ${ }^{[4,46,49]}$ hydride transfer to $\mathrm{O} 1$ of the peroxide bridge from $\mathrm{FADH}_{2}$ is coupled with heterolytic cleavage of the peroxide and synchronous unzipping with loss of the (protonated) C10 amino group in providing ring-opened tricarbonyl compound 22, which undergoes closure to the deoxydihydroartemisinin product 23 and its epimer 24 (Scheme $5 \mathrm{~A}$ ). ${ }^{[4]}$ Significantly, analogous processes occur for artemether (4) and artesunate (5), that is, no products are obtained from this heterolytic process that retain the original group attached to $\mathrm{C}^{10} .^{[4]}$ In the more specialized cases of $\mathrm{C} 10$ aminoartemisinins, hydride transfer must be facilitated by protonation of the nitrogen atom, as illustrated for artemisone in Scheme 5 A. Thus, in terms of the cofactor model, the feebler antimalarial activities of the methylene homologues becomes apparent-there is no leaving group at C10, and therefore, this process terminates with the formation of amino intermediate 25, which transforms into deoxy product $\mathbf{2 6}$ and the various other products arising from 25 by intramolecular condensation or dehydration pathways.

At first sight, this implies that carba analogues of artemisinins, that is, those bearing a carbon atom in place of the heteroatom attached to C10, may be intrinsically less active as antimalarial agents, even though the carba analogues will be more lipophilic. Such an activity difference is more likely to be revealed by comparison of in vitro data, for which differences due to permeation, metabolism, and other pharmacokinetic aspects will be less important. The carba analogue $\mathbf{2 6}$ (calculated $\log P$ 4.11) of artemether (3) (calcd $\log P$ 3.51) prepared from artemisinic acid ${ }^{[50,51]}$ is less active than artemether (3). Treatment of CQ-resistant K1 and CQ-sensitive FC27 strains of $P$. falciparum with $5 \mathrm{~nm}$ artemether (3) and carba analogue 26 resulted in 100 and $45 \%$ inhibition respectively. ${ }^{[51]}$ Carba analogues of artesunate (4) are unknown, ${ }^{[50]}$ but compound 27 by way of an approximate structural analogue is equipotent with artemisinin in vitro against the CQ-resistant W2 and CQ-sensitive D6 strains, ${ }^{[52]}$ that is, it is some fivefold less active than artesunate. ${ }^{[26]}$ However, such comparison of in vitro data between compound sets needs to be performed with care, as such data should be gathered at the same time by using the same assay methods for the respective compounds. An unequivocal answer to the C10 leaving group hypothesis can only be provided by a systematic examination of compound sets closely related by virtue of physicochemical properties, especially in relation to lipophilicity and spatial requirements, with one subset bearing leaving groups at $\mathrm{C} 10$ and the other bearing a carbon-linked or other "non-leaving" group at C10.

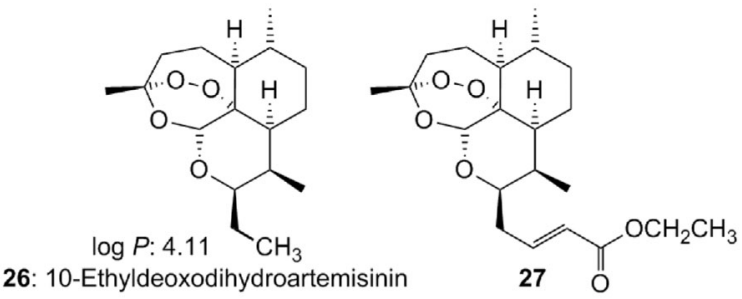

As we have pointed out elsewhere, ${ }^{[15]}$ the connectivity between the heteroatom attached to $\mathrm{C} 10$ and non-peroxidic oxygen atoms with juxtaposed carbon atoms, as indicated in Scheme 6, makes for an approximate " $W$ " conformation that must modulate electrophilicity of the peroxide. Further, hydride transfer from $\mathrm{FADH}_{2}$ to $\mathrm{O} 1$ in artemisone (Scheme $5 \mathrm{~A}$ ) is associated with synchronous ring opening to generate the ring-opened reduction product 22 . Thus, it is of interest to speculate that the nature of the leaving group attached to $\mathrm{C} 10$ may become important; ideally, it will be one that will be activated, for example, by protonation in the biological medium at essentially neutral $\mathrm{pH}$. However, the dichotomy that leads to an $\mathrm{S}_{\mathrm{N}} 1$ process, as illustrated in Scheme 1 , under overtly acidic conditions must be borne in mind; such can be obviated, for example, by suitable formulations of the drug that resist gastric $\mathrm{pH}$. Be that as it may, it is apparent that artemisinin derivatives bearing an amino group attached directly to C10 are appreciably more active in vitro than their acetal counterparts such as artemether (3), as exemplified by data for compounds 6-9 as discussed above.

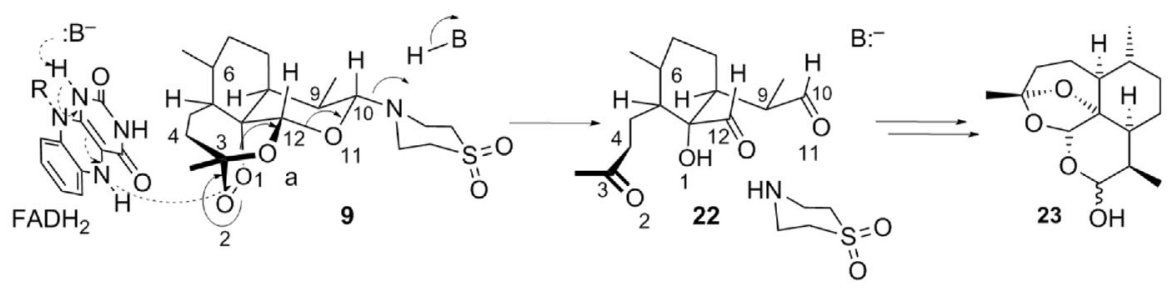

Scheme 6. Representation of hydride transfer from $\mathrm{FADH}_{2}$ to $\mathrm{O} 1$ of artemisone (9) in synchrony with cleavage of the peroxide $\mathrm{O} 1-\mathrm{O} 2$ bond leading to the formation of ring-opened product 22 (Scheme 5). The approximate $\mathrm{W}$-conformation of $\mathrm{N}^{1}$ '-C10-O11-C12 may allow transmission of inductive effects to the peroxide and for subsequent concerted fragmentation triggered by the addition of hydride to 01. 


\section{Conclusions}

Artemisone (9) exhibits potent antimalarial activities, and like other compounds in its class, it provides a compelling starting point for a drug-discovery effort based on this important class of therapeutic agent. In commencing this work, we prepared two artemisone homologues in which the thiomorpholine S,Sdioxide group is attached through a methylene linker to $\mathrm{C} 10$ and which differ in stereochemistry at C10. These were designed to have improved hydrolytic, thermal, and metabolic stabilities and by analogy with unnatural $C$-glycosides vis-à-vis their biologically active natural $\mathrm{N}$-glycoside counterparts were anticipated to possess enhanced biological activities. However, in relation to biological activities, the converse turned out to be true. The observations tend to suggest that the presence of a leaving group at $\mathrm{C} 10$ of the artemisinin skeleton may influence the biological activity in a positive sense. This may be rationalized by our cofactor model, wherein in terms of compatibility with, and activation by proton transfer from, the biological environment, an amino group at C10 appears to be ideal. This in turn suggests that structurally more elaborate artemisinins, for example, dimers or trimers attached at C10 through carba-based linkers that display promising biological activities $^{[53]}$ may be rendered even more active by use of aminobased linkers. Of course, the overall benefit may be ameliorated by the lower stability of the amino compounds in a biological medium, and as a result, lower biological half-lives. Thereby, the ultimate choice will rely on a cost-benefit analysis in relation to accessibility of the artemisinin derivative, its efficacy, toxicity, and the specific nature of the target.

Note added in proof: In relation to the mechanism, a referee suggested that one should take cognizance of the reports purporting to indicate that artemisinins and synthetic trioxolanes tagged with alkyl chains bearing terminal alkyne or azide groups evidently "alkylate" a considerable number of intraparasitic protein targets, a process that is enhanced by heme iron. ${ }^{[54]}$ What is apparent is that according to precedent for lipophilic drugs, the technique confirms promiscuous binding to proteins that are not necessarily associated with mechanism of action. ${ }^{[55]}$ More importantly, the terminal alkyne or azide tag very likely will sequester redox-active iron (either associated with heme or labile) and, of course, copper ${ }^{[56]}$ through the formation of alkyne or azide metal complexes, which thereby would lead to an artificial heme or redox metal ion effect. Induced decomposition of the peroxide in the artemisinin or synthetic trioxolane constrained by the proximate alkyne- or azide-bound heme or redox metal in the intraparasitic environment will ensue. One has to wonder how the putative tagged decomposition products-ketones, aldehydes, epoxides, and so on that do not possess antimalarial activities ${ }^{[26]}$-arising from redox metal ion catalyzed isomerization of the peroxide bridge in the artemisinin ${ }^{[57]}$ or synthetic peroxide may bind to the proteins. In general, a terminal alkyne tag may be used successfully as a surrogate for mapping behavior of endogenous substrates such as alkenes ${ }^{[58]}$ that do not possess bioactive peroxide groups. Further, terminal alkynes are potent mechanism-based inactivators of cytochrome P450 enzymes caused by association of the alkyne with the heme iron. ${ }^{[59]}$ In summary, it is premature to infer that the binding of the alkyne- and azide-tagged artemisinins and trioxolanes to proteins is mechanistically significant. Considerations of intrinsic chemistry as experimentally verified under biologically realistic conditions underscore the inability of artemisinins to undergo "activation" by heme-Fe" or Fe" and that further the putative exquisitely oxygen-sensitive $C$ radicals derived from reductive cleavage of the peroxide cannot alkylate "important" biomolecules in what is a patently oxidizing and relatively oxygen-rich environment within the intraerythrocytic parasite. ${ }^{[2]}$

\section{Experimental Section}

\section{General}

Dihydroartemisinin was obtained from the Kunming Pharmaceutical Corporation, Kunming, China, or from Haphacen, Hanoi College of Pharmacy, Vietnam. Other chemicals were purchased from commercial sources and were used without further purification. Dichloromethane was distilled from calcium hydride. Diethyl ether and tetrahydrofuran were dried with sodium and distilled from sodium benzophenone ketyl prior to use. $\mathrm{N}, \mathrm{N}$-Dimethylformamide was dried with calcium hydride, vacuum distilled, and stored over type $4 \AA$ molecular sieves under an atmosphere of nitrogen. Ethyl acetate and hexane for column chromatography were distilled from calcium chloride. Triethylamine was dried with calcium hydride and stored over sodium hydroxide pellets. 'H NMR spectra were recorded in $\mathrm{CDCl}_{3}$ with a Bruker-400 spectrometer, and ${ }^{13} \mathrm{C}$ NMR spectra were recorded in $\mathrm{CDCl}_{3}$ with a Bruker-300 spectrometer. Infrared spectra were recorded with a PerkinElmer Spectrum One spectrometer. Single-crystal $X$-ray structure measurements were performed with a Bruker Smart-APEX CCD four-circle diffractometer. All computations in the structure determination and refinement were performed on Silicon Graphics Indy computer by using programs of the Siemens SHELXTL PLUS (version 5) package. Melting points were recorded with a Leica Microscope Heating Stage 350 and are corrected. E. coli flavin reductase (Fre) was prepared as previously described ${ }^{[46,47]}$ and was stored in phosphate-buffered saline (PBS, $\mathrm{pH} 7.4$ ) containing $10 \%$ glycerol at $-20^{\circ} \mathrm{C}$ until use. UV/Vis spectra were recorded with a PerkinElmer Lambda 900 UV/Vis/near-IR double beam spectrometer and Varian Cary 50 UV spectrometer. Mass spectra were obtained with a GCT Premier Mass Spectrometer by Waters Micromass operating in chemical ionization $(\mathrm{Cl})$ mode, with $\mathrm{CH}_{4}$ or $\mathrm{NH}_{3}$ as the $\mathrm{Cl}$ reagent gas.

\section{Synthesis}

10 $\beta$-Cyano-10-deoxo-10-dihydroartemisinin (17): Tin(IV) chloride (93.6 $\mu \mathrm{L}, 0.8 \mathrm{mmol}, 0.4$ equiv) in dichloromethane $(1 \mathrm{~mL})$ was added to a stirred solution of $10 \beta$-dihydroartemisinyl benzoate (16; $0.78 \mathrm{~g}, 2 \mathrm{mmol}, 1$ equiv) and trimethylsilyl cyanide $(0.75 \mathrm{~mL}$, $6 \mathrm{mmol}, 3$ equiv) in dichloromethane $(5 \mathrm{~mL})$ at $-78^{\circ} \mathrm{C}$. The mixture was stirred for $2 \mathrm{~h}$ and was then treated with hydrochloric acid $(2 \mathrm{M}, 3 \mathrm{~mL})$. The mixture was extracted with dichloromethane $(3 \mathrm{x}$ $10 \mathrm{~mL}$ ). The organic layers were combined, and the organic solution was washed with water $(2 \times 10 \mathrm{~mL})$ and saturated aqueous $\mathrm{NaHCO}_{3}$ solution $(2 \times 10 \mathrm{~mL})$ and then dried $\left(\mathrm{MgSO}_{4}\right)$. After filtration, the filtrate was concentrated under reduced pressure to leave a crystalline residue. This was recrystallized directly from isopropanol to give the product as fine colorless needles $(0.97 \mathrm{~g}, 83 \%)$; mp: 
162-166 ${ }^{\circ} \mathrm{C} ;{ }^{1} \mathrm{H}$ NMR: $\delta=0.94-1.04(\mathrm{~m}, 1 \mathrm{H}), 0.98(\mathrm{~d}, J=6.4 \mathrm{~Hz}, 3 \mathrm{H}$ 6-Me), 1.07 (d, J=7.6 Hz, 3 H, 9-Me), 1.26-1.33 (m, 1 H), $1.43(\mathrm{~s}, 3 \mathrm{H}$, 3-Me), 1.46-1.54 (m, 2H), 1.60-1.65 (m, 1H), 1.74-1.86 (m, 2H), 2.04-2.10 (m, 1 H), 2.33-2.41 (m, 1 H), 2.84-2.93 (m, 1 H), $4.77(\mathrm{~d}$, $J=6 \mathrm{~Hz}, 1 \mathrm{H}, \mathrm{H}-10), 5.53 \mathrm{ppm}(\mathrm{s}, 1 \mathrm{H}, \mathrm{H}-12) ;{ }^{13} \mathrm{C} \mathrm{NMR}: \delta=13.022$ 20.16, 21.87, 24.44, 25.78, 28.91, 34.10, 35.97, 37.13, 44.44, 52.34, 65.75, 60.16, 90.34, 104.67, 117.91 ppm; IR (KBr): $\tilde{v}=491,537,596$ $641,713,825,841,858,884,913,937,958,981,1015,1044,1053$, $1065,1094,1122,1149,1190,1175,1209,1229,1244,1259,1278$, 1306, 1334, 1384, 1458, 2879, $2943 \mathrm{~cm}^{-1}$; MS: $\mathrm{m} / \mathrm{z}$ : calcd for $\mathrm{C}_{16} \mathrm{H}_{24} \mathrm{NO}_{4}{ }^{+} ; 294.1705[\mathrm{M}+\mathrm{H}]^{+}$; found: 294.1736 . These data are in agreement with reported values. ${ }^{[37]}$

$10 \alpha$-Aminocarbonyl-10-deoxo-10-dihydroartemisinin (18): A mixture consisting of nitrile $17(0.293 \mathrm{~g}, 1 \mathrm{mmol})$, potassium hydroxide $(0.196 \mathrm{~g}, 3.5 \mathrm{mmol}, 3.5$ equiv), and tert-butyl alcohol $(10 \mathrm{~mL})$ was stirred at $50^{\circ} \mathrm{C}$ in an oil bath for $3.5 \mathrm{~h}$. Brine $(10 \mathrm{~mL})$ and water $(5 \mathrm{~mL})$ were then added, and the mixture was cooled to ambient temperature. The resulting solution was extracted with diethyl ether $(3 \times 10 \mathrm{~mL})$. The organic layers were combined and dried $\left(\mathrm{MgSO}_{4}\right)$. After filtration, the filtrate was concentrated under reduced pressure to give product 18 as white plates $(0.226 \mathrm{~g}, 99 \%)$; $\mathrm{mp}: 75-81^{\circ} \mathrm{C} ;[\alpha]_{\mathrm{D}}^{20}=+154.03\left(c=0.62\right.$ in $\left.\mathrm{CHCl}_{3}\right) ;{ }^{1} \mathrm{H}$ NMR: $\delta=0.95$ (d, J=7.2 Hz, 3H, 6-Me), 0.97 (d, J=6 Hz, 3H, 9-Me), 1.03-1.10 (m, $1 \mathrm{H}), 1.25-1.43(\mathrm{~m}, 3 \mathrm{H}), 1.46(\mathrm{~s}, 3 \mathrm{H}, 3-\mathrm{Me}), 1.47-1.59(\mathrm{~m}, 2 \mathrm{H}), 1.72$ $1.79(\mathrm{~m}, 2 \mathrm{H}), 1.88-1.92(\mathrm{~m}, 1 \mathrm{H}), 2.02-2.07(\mathrm{~m}, 1 \mathrm{H}), 2.35-2.43(\mathrm{~m}$, $1 \mathrm{H}), 2.48-2.53(\mathrm{~m}, 1 \mathrm{H}), 3.91(\mathrm{~d}, J=11.2 \mathrm{~Hz}, 1 \mathrm{H}, \mathrm{H}-10), 5.32(\mathrm{~s}, 1 \mathrm{H}$, $\mathrm{H}-12), 5.36(\mathrm{~s}, 1 \mathrm{H}, \mathrm{NH}), 6.56 \mathrm{ppm}(\mathrm{s}, 1 \mathrm{H}, \mathrm{NH}) ;{ }^{13} \mathrm{C} \mathrm{NMR}: \delta=13.48$, $20.18,20.99,24.71,25.94,31.22,31.44,33.91,36.08,37.36,46.12$, $51.63,80.28,91.39,108.52,173.20 \mathrm{ppm}$; IR (KBr): $\tilde{\nu}_{\max }=510,563$, $607,697,761,929,851,878,915,941,1043,1060,1087,1134$, $1196,1228,1245,1280,1381,1453,1612,1637,1663,1693,2872$, 2937, 3254, 3470, 3497, $3550 \mathrm{~cm}^{-1}$; MS: $\mathrm{m} / \mathrm{z}$ : calcd for $\mathrm{C}_{16} \mathrm{H}_{26} \mathrm{NO}_{5}{ }^{+}$: 312.1811; found: $312.1809[\mathrm{M}+\mathrm{H}]^{+}$

10 $\beta$-Aminocarbonyl-10-deoxo-10-dihydroartemisinin (19): A mixture consisting of nitrile 17 (293 mg, $1 \mathrm{mmol})$, tetrahydrofuran $(5 \mathrm{~mL})$, water $(10 \mathrm{~mL})$, potassium carbonate $(152 \mathrm{mg}, 1.1 \mathrm{mmol}$, 1.1 equiv) and hydrogen peroxide $(2 \mathrm{~mL}, 15 \mathrm{mmol}, 30 \% \mathrm{v} / \mathrm{w}$, 15 equiv) was stirred for $2 \mathrm{~h}$ at room temperature. It was then heated, with stirring, at $40^{\circ} \mathrm{C}$ for $30 \mathrm{~min}$. After cooling the reaction mixture to ambient temperature, this was extracted with ethyl acetate $(3 \times 5 \mathrm{~mL})$. The organic layers were combined, and the organic solution was washed with water $(2 \times 5 \mathrm{~mL})$ and then dried over $\mathrm{MgSO}_{4}$. After filtration, the filtrate was concentrated by evaporation under reduced pressure to leave a crystalline residue. This was submitted to chromatography with ethyl acetate to give product 19 as white plates (91 mg, $29 \%)$; $\mathrm{mp}: 157-165^{\circ} \mathrm{C},[\alpha]_{\mathrm{D}}^{20}=+21.8$ $\left(c=0.55, \mathrm{CHCl}_{3}\right) .{ }^{1} \mathrm{H}$ NMR: $\delta=0.91-0.98(\mathrm{~m}, 1 \mathrm{H}), 0.97(\mathrm{~d}, J=6 \mathrm{~Hz}$, $3 \mathrm{H}, 9-\mathrm{Me}), 1.10(\mathrm{~d}, J=7.6 \mathrm{~Hz}, 3 \mathrm{H}, 6-\mathrm{Me}), 1.41$ (s, 3H, 3-Me), 1.12$1.45(\mathrm{~m}, 4 \mathrm{H}), 1.65-1.85(\mathrm{~m}, 3 \mathrm{H}), 1.92-2.32(\mathrm{~m}, 2 \mathrm{H}), 2.31-2.39(\mathrm{~m}$, $1 \mathrm{H}), 2.84-2.93(\mathrm{~m}, 1 \mathrm{H}), 4.81(\mathrm{~d}, J=6.2 \mathrm{~Hz}, 1 \mathrm{H}, \mathrm{H}-10), 5.42(\mathrm{~s}, 1 \mathrm{H}$, $\mathrm{NH}), 5.48(\mathrm{~s}, 1 \mathrm{H}, \mathrm{H}-12), 6.56 \mathrm{ppm}(\mathrm{s}, 1 \mathrm{H}, \mathrm{NH}) ;{ }^{13} \mathrm{C} \mathrm{NMR}: \delta=13.05$ 20.25, 24.32, 25.04, 25.99, 29.97, 34.41, 36.57, 37.76, 43.97, 51.88, 73.89, 81.21, 90.52, 103.49, 174.55 ppm; IR (KBr): $\tilde{v}=600,826,884$, 958, 1004, 1014, 1112, 1377, 1454, 1593, 1685, 2876, 2937, 3218, 3286, 3436, $3490 \mathrm{~cm}^{-1}$; MS: $\mathrm{m} / \mathrm{z}$ : calcd for $\mathrm{C}_{16} \mathrm{H}_{26} \mathrm{NO}_{5}{ }^{+}: 312.1811$ $[M+\mathrm{H}]^{+}$; found: 312.1828 .

$10 \alpha$-Aminomethylene-10-deoxo-10-dihydroartemisinin (20) and $10 \alpha$-methylene artemisone (14): $\mathrm{BF}_{3} \cdot \mathrm{OEt}_{2}(0.62 \mathrm{~mL}, 5.0 \mathrm{mmol})$ was added slowly to a stirred mixture of $10 \alpha$-aminocarbonyl-10-deoxyartemisinin $(19 ; 311 \mathrm{mg}, 1.0 \mathrm{mmol})$ and sodium borohydride $(190 \mathrm{mg}, 5.0 \mathrm{mmol})$ in dry tetrahydrofuran $(10 \mathrm{~mL})$ under an atmosphere of nitrogen. The mixture was then heated under reflux for
$2 \mathrm{~h}$. The mixture was cooled to ambient temperature and quenched by the slow addition of water $(20 \mathrm{~mL})$. The mixture was extracted with dichloromethane $(3 \times 30 \mathrm{~mL})$. The organic extracts were combined, washed with brine $(20 \mathrm{~mL})$, and dried $\left(\mathrm{MgSO}_{4}\right)$. After filtration and evaporation, crude amine $\mathbf{2 0}$ was used directly without further purification; attempts at purification resulted in its decomposition. Characteristic ${ }^{1} \mathrm{H}$ NMR signals for compound 20 $\delta=3.68-3.73(\mathrm{~m}, 1 \mathrm{H}, \mathrm{H}-10), 5.27 \mathrm{ppm}(\mathrm{s}, 1 \mathrm{H}, \mathrm{H}-12)$. A solution containing crude amine $20(200 \mathrm{mg})$ and divinyl sulfone $(0.1 \mathrm{~mL}$, $1.0 \mathrm{mmol})$ in propan-2-ol $(10 \mathrm{~mL})$ was heated under reflux for $2 \mathrm{~h}$. The solvent was removed under vacuum. The residue was purified by using column chromatography (hexane/ethyl acetate $2: 1$ ) to afford a white crystalline product $(145 \mathrm{mg}, 34.9 \mathrm{mmol}$ ( $40 \%$ from amide 18). This was recrystallized from methanol to give 14 as colorless needles; mp: $135.2-135.9{ }^{\circ} \mathrm{C} ;{ }^{1} \mathrm{H}$ NMR: $\delta=0.80-0.82$ (d, J= $6.8 \mathrm{~Hz}, 3 \mathrm{H}, 9-\mathrm{Me}), 0.95-0.97(\mathrm{~d}, J=6.4 \mathrm{~Hz}, 3 \mathrm{H}, 6-\mathrm{Me}), 1.03-1.51(\mathrm{~m}$, $7 \mathrm{H}), 1.34(\mathrm{~s}, 3 \mathrm{H}, 3-\mathrm{Me}), 1.66-2.04(\mathrm{~m}, 5 \mathrm{H}), 2.30-2.38(\mathrm{td}, J=3.6$, $14.0 \mathrm{~Hz}, 1 \mathrm{H}), 2.58-2.61(\mathrm{~m}, 1 \mathrm{H}), 2.62-2.67(\mathrm{dd}, J=5.2,14.0 \mathrm{~Hz}, 1 \mathrm{H}$, $-\mathrm{CH}_{2}-$ ) , 2.83-2.87 (dd, $\left.J=1.6,14.0 \mathrm{~Hz}, 1 \mathrm{H},-\mathrm{CH}_{2}-\right), 3.06-3.09(\mathrm{~m}, 6 \mathrm{H})$, 3.40-3.45 (m, 2H), 3.53-3.57 (m, $1 \mathrm{H}, \mathrm{H}-10), 5.21 \mathrm{ppm}(\mathrm{s}, 1 \mathrm{H}, \mathrm{H}-12)$; ${ }^{13} \mathrm{C}$ NMR $\left(300 \mathrm{MHz}, \mathrm{CDCl}_{3}\right): \delta=14.03,20.36,21.57,24.86,26.06$, $28.88,34.22,36.24,37.52,45.79,51.51,51.85,51.96,57.48,74.56$, 80.67, 91.65, 91.68, 104.21 ppm; IR (film): $\tilde{v}=824,840,858,880$, $903,925,943,968,993,1012,1022,1043,1063,1088,1099,1123$, 1190, 1218, 1226, 1242, 1272, 1302, 1330, 1376, 1452, 1631, 2842, 2870, 2917, $3448 \mathrm{~cm}^{-1}$; MS: $\mathrm{m} / \mathrm{z}$ : calcd for $\mathrm{C}_{20} \mathrm{H}_{34} \mathrm{NO}_{6} \mathrm{~S}^{+}: 416.2101$ $[M+\mathrm{H}]^{+}$; found: 416.2120 .

10 $\beta$-Aminomethylene-10-deoxo-10-dihydroartemisinin (21) and $10 \beta$-methyleneartemisone (15): $\mathrm{BF}_{3} \cdot \mathrm{OEt}_{2}(0.62 \mathrm{~mL}, 5.0 \mathrm{mmol})$ was added slowly to a stirred mixture of $10 \beta$-cyano-10-deoxyartemisinin $(17 ; 293 \mathrm{mg}, 1.0 \mathrm{mmol})$ and sodium borohydride $(190 \mathrm{mg}$, $5.0 \mathrm{mmol})$ in dry tetrahydrofuran $(10 \mathrm{~mL})$ under an atmosphere of nitrogen. The mixture was heated under reflux for $2 \mathrm{~h}$ and then cooled to ambient temperature, which was followed by careful quenching with water $(20 \mathrm{~mL})$. The mixture was extracted with dichloromethane $(3 \times 30 \mathrm{~mL})$. The organic portion was combined, washed with brine $(20 \mathrm{~mL})$, and dried $\left(\mathrm{MgSO}_{4}\right)$. After filtration and evaporation, milky crude amine 21 (167 mg) was obtained. Because this could not be adequately purified, it was used directly. Characteristic signals for compound 21: ${ }^{1} \mathrm{H}$ NMR (400 MHz, $\mathrm{CDCl}_{3}$ ): $\delta=4.43-4.78(\mathrm{~m}, 1 \mathrm{H}, \mathrm{H}-10), 5.32 \mathrm{ppm}(\mathrm{s}, 1 \mathrm{H}, \mathrm{H}-12)$. A solution of $10 \beta$-aminomethylene-10-deoxyartemisinin (21; $167 \mathrm{mg}, 0.4 \mathrm{mmol})$ and divinyl sulfone $(84 \mu \mathrm{L}, 0.84 \mathrm{mmol})$ in isopropanol $(6 \mathrm{~mL})$ was heated under reflux for $2 \mathrm{~h}$. The solvent was removed under reduced pressure, and the residue was purified by column chromatography (hexane/ethyl acetate 3:2 then 1:1) to afford a white crystalline product $(123 \mathrm{mg}, 0.30 \mathrm{mmol})$ in an overall yield of $45 \%$ from nitrile 17. The homologue was recrystallized from methanol to afford colorless needles; mp: $102.1-102.6^{\circ} \mathrm{C} ;{ }^{1} \mathrm{H}$ NMR: $\delta=0.87-$ $0.88(\mathrm{~d}, J=7.2 \mathrm{~Hz}, 3 \mathrm{H}, 9-\mathrm{Me}), 0.96-0.98(\mathrm{~d}, J=6.0 \mathrm{~Hz}, 3 \mathrm{H}, 6-\mathrm{Me})$, 1.03-1.51 (m, 6H), $1.65(\mathrm{~s}, 3 \mathrm{H}, 3-\mathrm{Me}), 1.65-2.13(\mathrm{~m}, 6 \mathrm{H}), 2.28-2.36$ $(\mathrm{td}, J=4.0,13.6 \mathrm{~Hz}, 1 \mathrm{H}), 2.54-2.62(\mathrm{~m}, 2 \mathrm{H}), 2.73-2.78(\mathrm{dd}, J=8.8$, $\left.13.6 \mathrm{~Hz}, 1 \mathrm{H},-\mathrm{CH}_{2}-\right), 3.06-3.22(\mathrm{~m}, 8 \mathrm{H}), 4.56-4.60(\mathrm{~m}, 1 \mathrm{H}, \mathrm{H}-10)$, 5.33 ppm (s, $1 \mathrm{H}, \mathrm{H}-12) ;{ }^{13} \mathrm{C}$ NMR $\left(300 \mathrm{MHz} \mathrm{CDCl}_{3}\right): \delta=12.08,20.11$, 24.83, 26.02, 30.21, 34.27, 36.58, 37.55, 43.72, 50.89, 51.52, 51.91, 56.52, 71.83, 81.08, 90.01, 90.03, 102.93 ppm; IR (film): $\tilde{v}=824,848$, $877,914,936,947,971,1016,1043,1055,1091,1125,1189,1231$, 1267, 1279, 1303, 1332, 1380, 1454, 1641, 2857, 2933, 3523, $3595 \mathrm{~cm}^{-1}$; MS: $\mathrm{m} / \mathrm{z}$ : calcd for $\mathrm{C}_{20} \mathrm{H}_{34} \mathrm{NO}_{6} \mathrm{~S}^{+} ; 416.2107[\mathrm{M}+\mathrm{H}]^{+}$; found: 416.2098 . 


\section{UV experiments}

Oxidation of $F A D H_{2}$ by artemisone (9) to $F A D$ : The artemisone solution was prepared from artemisone $(100.8 \mathrm{mg}, 0.251 \mathrm{mmol})$ and degassed MeCN $(5 \mathrm{~mL})$ to give a final concentration of $0.0502 \mathrm{M}$. The NADH solution was prepared from NADH $(17.0 \mathrm{mg}$, $0.0229 \mathrm{mmol})$ and degassed $\mathrm{pH} 7.4$ aqueous buffer $(1 \mathrm{~mL})$ to give a final calculated concentration of $0.0229 \mathrm{M}$. The absorbance of $\mathrm{NADH}$ measured at $\lambda_{\max }=339 \mathrm{~nm}$ was $0.3968905 \mathrm{AU}$, and the absorption coefficient at $\lambda_{\max }=339 \mathrm{~nm}$ was measured as $6220 \mathrm{M}^{-1} \mathrm{~cm}^{-1}$; therefore, the actual concentration of the NADH solution was $0.0116 \mathrm{M}$. The FAD solution was prepared from FAD $(8.4 \mathrm{mg}, 0.0101 \mathrm{mmol})$ and degassed $\mathrm{pH} 7.4$ aqueous buffer $(2 \mathrm{~mL})$ to give a final calculated concentration of $0.0051 \mathrm{M}$. The absorbance of FAD measured at $\lambda_{\max }=450 \mathrm{~nm}$ was $0.5819063 \mathrm{AU}$ and the absorption coefficient at $\lambda_{\max }=450 \mathrm{~nm}$ was $11300 \mathrm{M}^{-1} \mathrm{~cm}^{-1}$; therefore, the actual concentration of the FAD solution was $0.0047 \mathrm{M}$. The FAD reductase (Fre) was prepared in $\mathrm{pH} 7$ buffer to give a final concentration of $20 \mu \mathrm{M}$.

The degassed pH 7.4 buffer $(1900 \mu \mathrm{L})$ and the NADH solution ( $24 \mu \mathrm{L}, 0.278 \mu \mathrm{mol}, \approx 1.21$ equiv) were added to a UV cuvette ( $d=$ $1 \mathrm{~cm})$ at $22^{\circ} \mathrm{C}$ and treated with the Fre solution $(5 \mu \mathrm{L}, 0.1 \mathrm{nmol})$. A background was scanned from $\lambda=200$ to $800 \mathrm{~nm}$. The FAD solution ( $49 \mu \mathrm{L}, 0.230 \mathrm{nmol}, 1$ equiv) was added with mixing. Scanning was performed at $\lambda_{\max }=450 \mathrm{~nm}$ at $3 \mathrm{~s}$ intervals until the concentration of the FAD no longer decreased. Then, the effect of immediate addition of the artemisone solution $(8 \mu \mathrm{L}, 0.402 \mu \mathrm{mol}, \approx 2$ equiv) to the same cuvette on the rate of increase in the concentration of the FAD was performed by monitoring the increase in absorption due to FAD at $\lambda_{\max }=450 \mathrm{~nm}$ over $60 \mathrm{~min}$. The results are presented in Figure 2. The effect of adding the equivalent amount of degassed MeCN $(8 \mu \mathrm{L})$ containing no artemisone to the cuvette represents the blank experiment of Figure 2.

Oxidation of $\mathrm{FADH}_{2}$ by $\alpha$-methylene artemisone (14) to FAD: The methylene artemisone solution was prepared from 14 (20.8 mg, $0.0501 \mathrm{mmol})$ and degassed $\mathrm{MeCN}(1 \mathrm{~mL})$ to give a final concentration of $0.0501 \mathrm{M}$. The NADH, FAD, and Fre solutions were used as above. The degassed pH 7.4 buffer $(1900 \mu \mathrm{L})$ and the NADH solution ( $24 \mu \mathrm{L}, 0.278 \mu \mathrm{mol}, \approx 1.21$ equiv) were added to a UV cuvette $(d=1 \mathrm{~cm})$ at $22^{\circ} \mathrm{C}$ and treated with the Fre solution $(5 \mu \mathrm{L}$, $0.1 \mathrm{nmol}$ ). A background was scanned from $\lambda=200$ to $800 \mathrm{~nm}$. The FAD solution ( $49 \mu \mathrm{L}, 0.230 \mathrm{nmol}, 1$ equiv) was added with mixing. Scanning was performed at $\lambda_{\max }=450 \mathrm{~nm}$ at $3 \mathrm{~s}$ intervals until the concentration of FAD no longer decreased. Then, the effect of adding the solution of 14 ( $8 \mu \mathrm{L}, 0.402 \mu \mathrm{mol}, \approx 2$ equiv) to the cuvette on the rate of increase in FAD was performed by monitoring the increase in absorption due to FAD at $\lambda_{\max }=450 \mathrm{~nm}$ over 65 min (Figure 2).

Oxidation of $\mathrm{FADH}_{2}$ by $\beta$-methylene artemisone (15) to $F A D$ : The methylene artemisone solution was prepared from $15(20.6 \mathrm{mg}$, $0.0496 \mathrm{mmol})$ and degassed $\mathrm{MeCN}(1 \mathrm{~mL})$ to give a final concentration of $0.0496 \mathrm{M}$. The NADH, FAD, and Fre solutions were used as above, and the experiment was repeated according to the foregoing to give the result depicted in Figure 2.

\section{Reduction of $\alpha$-methylene artemisone 14}

A mixture of $14(37.4 \mathrm{mg}, 0.090 \mathrm{mmol})$, riboflavin $(6.8 \mathrm{mg}$, $0.018 \mathrm{mmol}, 0.2$ equiv), and $\mathrm{N}$-benzyl-1,4-dihydronicotinamide (BNAH; $38.6 \mathrm{mg}, 0.180 \mathrm{mmol}, 2$ equiv) in $\mathrm{MeCN} / \mathrm{pH} 7.4$ phosphate buffer $(1: 1,2.68 \mathrm{~mL})$ was stirred under an atmosphere of argon for $3 \mathrm{~h}$ at room temperature. The mixture was diluted with diethyl ether $(3 \mathrm{~mL})$, and the organic layer was separated. The aqueous layer was extracted with ethyl acetate $(3 \times 5 \mathrm{~mL})$. The combined organic layer was washed with brine $(2 \times 5 \mathrm{~mL})$ and then dried $\left(\mathrm{MgSO}_{4}\right)$. After filtration, the solution was concentrated under reduced pressure. The residue was submitted to chromatography (ethyl acetate/hexane/triethylamine 3:7:0.1) to give recovered 14 (3.8 mg, 10\%): MS: $\mathrm{m} / \mathrm{z}$ : calcd for $\mathrm{C}_{20} \mathrm{H}_{34} \mathrm{NO}_{6} \mathrm{~S}^{+}: 416.2101$; found: 416.2101. Next was eluted a fraction $(\approx 3 \mathrm{mg})$ consisting of a complex mixture that according to mass spectral analysis contained products equivalent to ring-opened precursor 25 (MS: $\mathrm{m} / \mathrm{z}$ : calcd for $\mathrm{C}_{20} \mathrm{H}_{36} \mathrm{NO}_{6} \mathrm{~S}^{+}$: 418.2258; found: 418.2232) and deoxy product 26 (MS: $\mathrm{m} / \mathrm{z}$ : calcd for $\mathrm{C}_{20} \mathrm{H}_{34} \mathrm{NO}_{5} \mathrm{~S}^{+}$: 400.2152; found: 400.2132). Prominent peaks at $\mathrm{m} / \mathrm{z}=388.2136$ (MS: $\mathrm{m} / \mathrm{z}$ : calcd for $\mathrm{C}_{19} \mathrm{H}_{34} \mathrm{NO}_{5} \mathrm{~S}^{+}$: 388.2152) and 370.2020 (MS: $\mathrm{m} / \mathrm{z}$ : calcd for $\mathrm{C}_{19} \mathrm{H}_{32} \mathrm{NO}_{4} \mathrm{~S}^{+}: 370.2047$ ) correlate with protonated molecular ions of products arising from degradation of the initial deoxy products. Fragmentation peaks correlating with $\beta$ cleavage of the carbonyl side chain and the methylene S,S-dioxo-4-thio-1-morpholine appendage in the primary products were also noted. The MS and details are given in Figure 56 a. A subsequent fraction isolated $(\approx 12 \mathrm{mg}$ ) was a mixture that according to mass spectral analysis contained the deoxy compound 25 (MS: $\mathrm{m} / \mathrm{z}$ : calcd for $\mathrm{C}_{20} \mathrm{H}_{34} \mathrm{NO}_{5} \mathrm{~S}^{+}$: 400.2152; found: 400.2162). Details are given in Figure S6b. However, attempts to repurify this sample for fuller characterization were not successful.

\section{Acknowledgements}

Work at the Hong Kong University of Science and Technology was performed in the Open Laboratory of Chemical Biology of the Institute of Molecular Technology for Drug Discovery and Synthesis with financial support from the Government of the HKSAR University Grants Committee Areas of Excellence Fund (Project Nos. AoE P/10-01/01-02-I and AOE/P-10/01-2-II) and the University Grants Council [Grant Nos. HKUST 6493/06M, and 600507]. Work at North-West University, South Africa, was performed under financial support from North-West University and was funded in part by the South African Medical Research Council (MRC) with funds from National Treasury under its Economic Competitiveness and Support Package.

Keywords: antimalarial activity - antitumor agents • Cglycosides $\cdot$ peroxides $\cdot$ mechanisms

[1] a) T. N. C. Wells, P. L. Alonso, W. E. Gutteridge, Nat. Rev. Drug Discovery 2009, 8, 879-891; b) M. Delves, D. Plouffe, C. Scheurer, S. Meister, S. Wittlin, E. A. Winzeler, R. E. Sinden, D. Leroy, PLoS Med. 2012, 9, e1001169.

[2] a) R. K. Haynes, H. W. Chan, C. M. Lung, N. C. Ng, H. N. Wong, L. Y. Shek, I. D. Williams, M. F. Gomes, A. Cartwright, ChemMedChem 2007, 2, 1448-1463; b) F. H. Jansen, Malar. J. 2010, 9, 212.

[3] K. F. Ilett, B. T. Ethell, J. L. Maggs, T. M. E. Davis, K. T. Batty, B. Burchell, T. Q. Binh, L. T. A. Thu, N. C. Hung, M. Pirmohamed, B. K. Park, G. Edwards, Drug Metab. Dispos. 2002, 30, 1005-1012.

[4] R. K. Haynes, W. C. Chan, H. N. Wong, K. Y. Li, W. K. Wu, K. M. Fan, H. Sung, I. D. Williams, D. Prosperi, S. Melato, P. Coghi, D. Monti, ChemMedChem 2010, 5, $1282-1299$.

[5] a) P. L. Olliaro, N. K. Nair, R. K. Haynes, M. M.-K. Tang, C. K.-W. Cheu, B. Zanolari, L. A. Decosterd, V. Navaratnam, unpublished results; b) S. Parapini, P. Olliaro, V. Navaratnam, D. Taramelli, N. Basilico, Antimicrob. Agents. Chemother. 2015, 59, 4046-4052.

[6] a) K. T. Batty, K. F. Ilett, T. Davis, M. E. Davis, J. Pharm. Pharmacol. 1996, 48, 22-26; b) Q. G. Li, J. O. Peggins, A. J. Lin, K. J. Masonic, K. M. Trot- 
man, T. G. Brewer, Trans. R. Soc. Trop. Med. Hyg. 1998, 92, 332-340 c) T. M. E. Davis, T. Q. Binh, K. F. Ilett, K. T. Batty, H. Phuöng, G. M. Chis well, V. D. Phuong, C. Agus, Antimicrob. Agents Chemother. 2003, 47 368-370; d) C. A. Morris, S. Duparc, I. Borghini-Fuhrer, D. Jung, C.-S. Shin, L. Fleckenstein, Malar. J. 2011, 10, 263.

[7] K. T. Batty, K. F. Ilett, S. M. Powell, J. Martin, T. M. E. Davis, Am. J. Trop. Med. Hyg. 2002, 66, 130-136.

[8] M. A. van Agtmael, V. Gupta, T. H. van der Wösten, J.-P. B. Rutten, C. J. van Boxtel, Eur. J. Clin. Pharmacol. 1999, 55, 405-410.

[9] a) T. G. Brewer, J. O. Peggins, S. J. Grate, J. M. Petras, B. S. Levine, P. J. Weina, J. Swearengen, M. H. Heiffer, B. G. Schuster, Trans. R. Soc. Trop. Med. Hyg. 1994, 88, 33-36; b) T. G. Brewer, S. J. Grate, J. O. Peggins, P. J. Weina, J. M. Petras, B. S. Levine, M. H. Heiffer, B. G. Schuster, Am. J. Trop. Med. Hyg. 1994, 51, 251-259; c) G. Schmuck, R. K. Haynes, Neurotoxic Res. 2000, 2, 37-49; d) G. Schmuck, E. Roehrdanz, R. K. Haynes, R. Kahl, Antimicrob. Agents Chemother. 2002, 46, 821-827.

[10] a) A. Nontprasert, M. Nosten-Bertrand, S. Pukrittayakamee, S. Vanijanonta, B. J. Angus, N. J. White, Am. J. Trop. Med. Hyg. 1998, 59, 519-522 b) R. F. Genovese, D. B. Newman, T. G. Brewer, Pharmacol. Biochem. Behav. 2000, 67, 37-44.

[11] a) R. Johann-Liang, R. Albrecht, Clin. Infect. Dis. 2003, 36, 1626-1627; b) T. Gordi, E.-I. Lepist, Toxicol. Lett. 2004, 147, 99-107; c) S. Toovey, A Jamieson, Toxicol. Lett. 2004, 151, 489-490; d) C. J. Woodrow, R. K. Haynes, S. Krishna, Artemisinins Postgrad. Med. J. 2005, 81, 71-78; e) S Toovey, Toxicol. Lett. 2006, 166, $95-104$; f) S. Toovey, Lancet 2006, 367 111-112; g) S. Toovey, Clin. Infect. Dis. 2006, 42, 1214-1215; h) S. Toovey, Am. J. Trop. Med. Hyg. 2006, 74, 939-940.

[12] R. F. Genovese, D. B. Newman, Arch. Toxicol. 2008, 82, 379-385.

[13] a) A.P. Phyo, S. Nkhoma, K. Stepniewska, E. A. Ashley, S. Nair, R. McGready, C. ler Moo, S. Al-Saai, A. M. Dondorp, K. M. Lwin, P. Singhasivanon, N. J. White, J. C. Anderson, F. Nosten, Lancet 2012, 379, 1960 1966; b) Y. Lubell, A. Dondorp, P. J. Guérin, T. Drake, S. Meek, E. Ashley N. P. J. Day, N. J. White, L. J. White, Malar. J. 2014, 13, 452; c) F. Ariey, B. Witkowski, C. Amaratunga, J. Beghain, A.-C. Langlois, N. Khim, S. Kim, V. Duru, C. Bouchier, L. Ma, P. Lim, R. Leang, S. Duong, S. Sreng, S. Suon, C. M. Chuor, D. M. Bout, S. Ménard, W. O. Rogers, B. Genton, T. Fandeur, O. Miotto, P. Ringwald, J. Le Bras, A. Berry, J.-C. Barale, R. M. Fairhurst, F. Benoit-Vical, O. Mercereau-Puijalon, D. Ménard, Nature 2014, 505, 50 55.

[14] S. Krishna, L. Bustamante, R. K. Haynes, H. M. Staines, Trends Pharmacol. Sci. 2008, 29, 520-527.

[15] R. K. Haynes, Curr. Med. Chem. 2006, 13, 509-537.

[16] B. J. Kim, T. Sasaki, Org. Prep. Proced. Int. 2006, 38, 1-80.

[17] L. Tilley, S. A. Charman, J. L. Vennerstrom in RSC Drug Discovery Series No. 14, Neglected Diseases and Drug Discovery (Eds.: M. J. Palmer, T. N. C. Wells), 2012, RSC Publishing, Cambridge (UK), pp. 33-64.

[18] a) K. Ramu, J. K. Baker, J. Med. Chem. 1995, 38, 1911-1921; b) A. K. Bhattacharjee, J. M. Karle, Chem. Res. Toxicol. 1999, 12, 422-428.

[19] R. K. Haynes, Curr. Opin. Infect. Dis. 2001, 14, 719-726.

[20] R. K. Haynes, W. Y. Ho, H. W. Chan, B. Fugmann, J. Stetter, S. L. Croft, L. Vivas, W. Peters, B. L. Robinson, Angew. Chem. Int. Ed. 2004, 43, 1381 1385; Angew. Chem. 2004, 116, 1405- 1409.

[21] R. K. Haynes, B. Fugmann, J. Stetter, K. Rieckmann, H. D. Heilmann, H. W. Chan, M. K. Cheung, W. L. Lam, H. N. Wong, S. L. Croft, L. Vivas, L. Rattray, L. Stewart, W. Peters, B. L. Robinson, M. D. Edstein, B. Kotecka, D. E. Kyle, B. Beckermann, M. Gerisch, M. Radtke, G. Schmuck, W. Steinke, U. Wollborn, K. Schmeer, A. Römer, Angew. Chem. Int. Ed. 2006, 45, $2082-$ 2088; Angew. Chem. 2006, 118, 2136-2142.

[22] a) G. Schmuck, M. Temerowski, R. K. Haynes, B. Fugmann, Res. Adv. Antimicrob. Agents Chemother. 2003, 3, 35-47; b) E. Von Keutz, G. Schmuck, R. K. Haynes, Abstracts of the Medicine and Health in the Tropics Congress, Marseille, France, 2005, Abstract no. O-004, p. 28.

[23] Calculated with the ChemBioDraw Ultra Version 11.0 structure drawing suite of programs with the algorithm developed in A. K. Ghose, G. M. Crippen, J. Chem. Inf. Comput. Sci. 1987, 27, 21-35.

[24] L. Vivas, L. Rattray, L. B. Stewart, B. L. Robinson, B. Fugmann, R. K. Haynes, W. Peters, S. L. Croft, J. Antimicrob. Chemother. 2007, 59, $658-$ 665.

[25] J. Marfurt, F. Chalfein, P. Prayoga, F. Wabiser, G. Wirjanata, B. Sebayang, K. A. Piera, S. Wittlin, R. K. Haynes, J. Möhrle, N. M. Anstey, E. Kenangalem, R. N. Price, Antimicrob. Agents Chemother. 2012, 56, 5258-5263.
[26] R. K. Haynes, K.-W. Cheu, D. N'Da, P. Coghi, D. Monti, Infect. Disord. Drug Targets 2013, 13, 217-277.

[27] a) J. H. Waknine-Grinberg, N. Hunt, A. Bentura-Marciano, J. A. McQuillan, H. W. Chan, W. C. Chan, Y. Barenholz, R. K. Haynes, J. Golenser, Malar. J. 2010, 9, 227; b) J. H. Waknine-Grinberg, S. Even-Chen, K. Turjeman, A. Bentura-Marciano, R. K. Haynes, L. Weiss, L. Allon, H. Ovadia, J. Golenser, Y. Barenholz, PLOS ONE 2013, 8, e72722.

[28] N. Obaldia, B. M. Kotecka, M. D. Edstein, R. K. Haynes, B. Fugmann, D. E. Kyle, K. H. Rieckmann, Antimicrob. Agents Chemother. 2009, 53, $3592-$ 3594.

[29] I. R. Dunay, W. C. Chan, R. K. Haynes, L. D. Sibley, Antimicrob. Agents Chemother. 2009, 53, 4450-4456.

[30] a) T. Efferth, H. Dunstan, A. Sauerbrey, H. Miyachi, C. R. Chitambar, Int. J. Oncol. 2001, 18, 767-773; b) G. Kelter, D. Steinbach, V. B. Konkimalla, T. Tahara, S. Taketani, H. H. Fiebig, T. Efferth, PLoS One 2007, 2, e798; c) H. J. Zhou, J. L. Zhang, A. Li, Z. Wang, X. E. Lou, Cancer Chemother Pharmacol. 2010, 66, 21-29.

[31] A. M. Gravett, W. M. Liu, S. Krishna, W. C. Chan, R. K. Haynes, N. L. Wilson, A. G. Dalgleish, Cancer Chemother. Pharmacol. 2011, 67, 569577.

[32] R. Hooft van Huijsduijnen, R. K. Guy, K. Chibale, R. K. Haynes, I. Peitz, G. Kelter, M. A. Phillips, J. L. Vennerstrom, Y. Yuthavong, T. N. C. Wells, PLoS ONE 2013, 8, e82962.

[33] C. M. Lung, M. Phil, Thesis, The Hong Kong University of Science and Technology, 2004.

[34] J. Jiménez-Barbero, J. F. Espinosa, J. L. Asensio, F. J. Cañada, A. Poveda Adv. Carbohydr. Chem. Biochem. 2000, 56, 235-284.

[35] a) R. Ravishankar, A. Surolia, M. Vijayan, S. Lim, Y. Kishi, J. Am. Chem. Soc 1998, 120, 11297-11303; b) J. F. Espinosa, F. J. Cañada, J. L. Asensio, M. Martín-Pastor, H. Dietrich, M. Martín-Lomas, R. R. Schmidt, J. JiménezBarbero, J. Am. Chem. Soc. 1996, 118, 10862-10871.

[36] J. Schmieg, G. Yang, R. W. Franck, M. Tsuji, J. Exp. Med. 2003, 198, 1631 1641.

[37] J. Ma, E. Katz, H. Ziffer, Tetrahedron Lett. 1999, 40, 8543-8545.

[38] R. K. Haynes, H. W. Chan, M. K. Cheung, W. L. Lam, M. K. Soo, H. W. Tsang, A. Voerste, I. D. Williams, Eur. J. Org. Chem. 2002, 113-132.

[39] The relative free energies of each of the $\alpha$ - and $\beta$-nitriles calculated with the HF/3-21G basis set indicate that the $\beta$-nitrile (i.e., compound 17 ) is more stable than the $\alpha$ epimer by $3.03 \mathrm{~kJ} \mathrm{~mol}^{-1}$.

[40] J. H. Hall, M. Gisler, J. Org. Chem. 1976, 41, 3769-3770.

[41] G. Jayson, J. Gradiner, S. Hansen (The University of Manchester, UK), US Pat. No. 2009/0137792A1, 2006.

[42] S.-D. Cho, Y.-D. Park, J.-J. Kim, J. R. Falck, Y.-J. Yoon, Bull. Korean Chem. Soc. 2004, 25, 407-409.

[43] A. H. Ford-Moore, J. Chem. Soc. 1949, 2433-2440.

[44] M. L. Teyssot, M. Fayolle, C. Philouze, C. Dupuy, Eur. J. Org. Chem. 2003, $54-62$.

[45] M. A. Avery, F.-L. Gao, W. K. M. Chong, S. Mehrotra, W. K. Milhous, J. Med. Chem. 1993, 36, 4264-4275.

[46] R. K. Haynes, K.-W. Cheu, M. M.-K. Tang, M.-J. Chen, Z.-F. Guo, Z.-H. Guo, P. Coghi, D. Monti, ChemMedChem 2011, 6, 279-291.

[47] Z. T. Campbell, T. O. Baldwin, J. Biol. Chem. 2009, 284, 8322-8328.

[48] a) F. Xu, K. S. Quandt, D. E. Hultquist, Proc. Natl. Acad. Sci. USA 1992, 89, 2130-2134; b) M. Ingelman, S. Ramaswamy, V. Nivière, M. Fontecave, H. Eklund, Biochemistry 1999, 38, 7040-7049; c) A. Kinoshita, Y. Nakayama, T. Kitayama, M. Tomita, FEBS J. 2007, 274, 1449-1458; d) F. Fieschi, V. Nivière, C. Frier, J. L. Décout, M. Fontecave, J. Biol. Chem. 1995, 270 30392-30400; e) V. Nivière, M. A. Vanoni, G. Zanetti, M. Fontecave, Biochemistry 1998，37, 11879-11887; f) B. A. Palfey, O. Björnberg，K. F. Jensen, Biochemistry 2001, 40, 4381-4390; g) M. Laclau, F. Lu, M. J. MacDonald, Mol. Cell. Biochem. 2001, 225, 151-160; h) L. J. Smith, S. Browne, A. J. Mulholland, T. J. Mantle, Biochem. J. 2008, 411, 475-484.

[49] R. K. Haynes, K.-W. Cheu, H.-W. Chan, H.-N. Wong, K.-Y. Li, M. M.-K. Tang, M.-J. Chen, Z.-F. Guo, Z.-H. Guo, K. Sinniah, A. B. Witte, P. Coghi, D. Monti, ChemMedChem 2012, 7, 2204-2226.

[50] a) R. K. Haynes, S. C. Vonwiller, Synlett 1992, 481-482; b) R. K. Haynes, S. C. Vonwiller, Acc. Chem. Res. 1997, 30, 73-79.

[51] R. K. Haynes, S. C. Vonwiller (The University of Sydney, Australia), Int. PCT Pub. No. WO1993008195A1, PCT/AU1992/000548, 1993.

[52] J. Ma, E. Katz, D. E. Kyle, H. Ziffer, J. Med. Chem. 2000, 43, 4228-4232. 
[53] R. C. Conyers, J. R. Mazzone, M. Siegler, A. K. Tripathi, D. J. Sullivan, B. T. Mott, G. H. Posner, Bioorg. Med. Chem. Lett. 2014, 24, 1285-1289.

[54] a) J. Wang, C. J. Zhang, W. N. Chia, C. C. Y. Loh, Z. Li, Y. M. Lee, Y. He, L. X. Yuan, T. K. Lim, M. Liu, C. X. Liew, Y. Q. Lee, J. Zhang, N. Lu, C. T. Lim, Z. C. Hua, B. Liu, H. M. Shen, K. S. W. Tan, Q. Lin, Nat. Commun. 2015, 6 10111; b) H. M. Ismail, V. Barton, M. Phanchana, S. Charoensutthivarakul, M. H. L. Wong, J. Hemingway, G. A. Biagini, P. M. O'Neill, S. A. Ward, Proc Natl. Acad. Sci. USA 2016, 113, 2080-2085; c) H. M. Ismail, V. E. Barton, M. Panchana, S. Charoensutthivarakul, G. A. Biagini, S. A. Ward, P. M. O'Neill, Angew. Chem. Int. Ed. 2016, 55, 6401-6405; Angew. Chem. 2016, $128,6511-6515$.

[55] D. B. Kell, P. D. Dobson, E. Bilsland, S. G. Oliver, Drug Discovery Today 2013, 18, 218-239.

[56] For the importance of copper in parasite physiology, see: $\mathrm{H}$. Asahi, M. E. M. Tolba, M. Tanabe, S. Sugano, K. Abe, F. Kawamoto, BMC Microbiol. 2014, 14, 167.
[57] R. K. Haynes, W. C. Chan, C.-M. Lung, A.-C. Uhlemann, U. Eckstein, D. Taramelli, S. Parapini, D. Monti, S. Krishna, ChemMedChem 2007, 2, 1480 1497.

[58] W. N. Beavers, R. Serwa, Y. Shimozu, K. A. Tallman, M. Vaught, E. D. Dalvie, L. J. Marnett, N. A. Porter, J. Am. Chem. Soc. 2014, 136, 11529 11539.

[59] a) G. A. Schoch, G. N. Nikov, W. L. Alworth, D. Werck-Reichhart, Plant Physiol. 2002, 130, $1022-1031$; b) H. L. Lin, P. F. Hollenberg, J. Pharmacol. Exp. Ther. 2007, 321, 276-287.

Received: January 7, 2016

Revised: May 13, 2016

Published online on $\square \mathbf{\square}, 0000$ 


\section{FULL PAPERS}

Managing malaria: Insertion of a methylene group between the S,S-dioxothiomorpholine ring and the artemisinin nucleus of artemisone generates homologues that are surprisingly less efficacious than artemisone. This may be explained by hydride transfer from $\mathrm{FADH}_{2}$ in flavin disulfide reductases that regulate redox homeostasis to the peroxide, activated by the $S, S$-dioxothiomorpholine leaving group in artemisone; such activation is absent in the homologues.

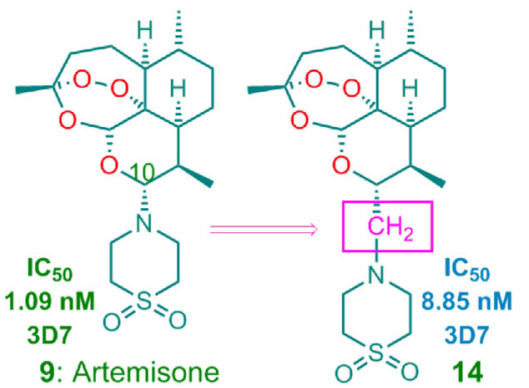

Y. Wu, R. W. K. Wu, K. W. Cheu, I. D. Williams, S. Krishna, K. Slavic, A. M. Gravett, W. M. Liu, H. N. Wong, R. K. Haynes*

Methylene Homologues of Artemisone: An Unexpected Structure-Activity Relationship and a Possible Implication for the Design of C10-Substituted Artemisinins 